\title{
A RELAÇÃO ENTRE DIREITO E DESENVOLVIMENTO: OTIMISTAS VERSUS CÉTICOS
}

\author{
Kevin E. Davis e Michael J. Trebilcock \\ THE RELATIONSHIP BETWEEN LAW AND DEVELOPMENT: \\ OPTIMISTS VERSUS SKEPTICS
} tradução Pedro Maia Soares ReVISÃo técnica José Rodrigo Rodriguez

\section{RESUMO}

ESTE ARTIGO EXAMINA PARTE DA PRODUC̄̃̃ MAIS RECENTE SOBRE DIREITO E DESENVOLVIMENTO, A PARTIR DE TRÊS LIVROS PUBLICADOS POR ESTUDIOSOS NORTE-AMERICANOS, AS COLETÂNEAS ORGANIZADAS POR THOMAS CAROTHERS E POR DAVID M. Trubek e Álvaro Santos, além da monografia de Kenneth Dam. O texto sugere que esses livros lou, aO MENOS, ALGUNS DOS ARTIGOS NELES REUNIDOS) REFLETEM UMA INSENSIBILIDADE PARA AS AMBIGUIDADES QUE CERCAM A RELAÇ̄̃O ENTRE REFORMA JURÍDICA E DESENVOLVIMENTO. MOSTRA QUE HÁ UM DEBATE EM ANDAMENTO SOBRE QUESTÕES FUNDAMENTAIS, TAIS COMO SE O DIREITO É UM FATOR IMPORTANTE PARA DETERMINAR RESULTADOS SOCIAIS OU ECONÔMICOS NAS SOCIEDADES EM DESENVOLVIMENTO, TENDO EM VISTA A EXISTÊNCIA DE MÉTODOS INFORMAIS DE CONTROLE SOCIAL; SE EXISTEM OBSTÁCULOS ECONÔMICOS, POLÍTICOS OU CULTURAIS INSUPERÁVEIS PARA UMA REFORMA JURÍDICA EFETIVA, BEM COMO, SUPONDO-SE QUE UMA REFORMA JURÍDICA EFETIVA SEJA FACTIVELL, QUE TIPOS DE REFORMAS SÃO CONDUCENTES AO DESENVOLVIMENTO E QUE TIPOS DE ATORES DEVEM IMPLEMENTÁ-LAS. SUSTENTAMOS QUE, EMBORA EXISTAM ALGUNS MOTIVOS PARA O OTIMISMO EM RELAÇÃO AO IMPACTO POTENCIAL DAS REFORMAS JURÍDICAS SOBRE O DESENVOLVIMENTO, A LITERATURA EMPÍRICA PERTINENTE É INCONCLUSIVA QUANTO A MUITAS QUESTÕES IMPORTANTES E ACONSELHA CAUTELA NO QUE DIZ RESPEITO AO INVESTIMENTO DE RECURSOS SUBSTANCIAIS NA PROMOÇĀO DE REFORMAS JURÍDICAS NOS PAÍSES EM DESENVOLVIMENTO SEM A REALIZAÇ̃̃O DE MAIS PESQUISAS QUE ESCLARECTAM ESSAS QUESTÕES.

\section{PALAVRAS-CHAVE}

DIREITO; DESENVOLVIMENTO; RULE OF LAW; REFORMA, PROGRAMAS.

\section{ABSTRACT}

THIS ARTICLE EXAMINES PART OF THE MOST RECENT INTELLECTUAL PRODUCTION ON LAW \& DEVELOPMENT BASED UPON THREE RECENTLY PUBLISHED BOOKS: TWO COLLECTIONS OF ESSAYS ORGANIZED BY THOMAS CAROTHERS AND BY DAVID M. TRUBEK AND ALVARO SANTOS, AND A MONOGRAPH BY KenNeth DAM. THE ARTICLE SHOWS that THERE IS ONGOING DEBATE ABOUT FUNDAMENTAL QUESTIONS SUCH AS WHETHER LAW IS AN IMPORTANT FACTOR IN DETERMINING SOCIAL OR ECONOMIC OUTCOMES IN DEVELOPING SOCIETIES GIVEN THE EXISTENCE OF INFORMAL METHODS OF SOCIAL CONTROL; WHETHER THERE ARE INSURMOUNTABLE ECONOMIC, POLITICAL OR CULTURE OBSTACLES TO EFFECTIVE LEGAL REFORM; AS WELL AS, ASSUMING EFFECTIVE LEGAL REFORM IS FEASIBLE, WHAT TYPES OF REFORMS ARE CONDUCIVE TO DEVELOPMENT AND WHAT TYPES OF ACTORS OUGHT TO IMPLEMENT THEM. WE ARGUE THAT ALTHOUGH THERE ARE SOME REASONS FOR OPTIMISM ABOUT THE POTENTIAL IMPACT OF LEGAL REFORMS UPON DEVELOPMENT, THE RELEVANT EMPIRICAL LITERATURE IS INCONCLUSIVE ON MANY IMPORTANT ISSUES AND COUNSELS CAUTION ABOUT THE WISDOM OF CONTINUING TO INVEST SUBSTANTIAL RESOURCES IN PROMOTING LEGAL REFORM IN DEVELOPING COUNTRIES WITHOUT FURTHER RESEARCH THAT CLARIFIES THESE ISSUES.

\section{KEYWORDS}

LAW; DEVELOPMENT; RULE OF LAW; REFORM, PROGRAMS. 
as duas últimas décadas, ressurgiu o interesse, tanto de acadêmicos como de profissionais, em usar o direito para promover o desenvolvimento na América Latina, África subsaariana, Europa central e oriental e Ásia. O grau do interesse acadêmico pelo tópico reflete-se na publicação recente de três livros sobre direito e desenvolvimento por proeminentes estudiosos americanos: Thomas Carothers (ed.), Promoting the Rule of Law Abroad: In Search of Knowledge; Kenneth Dam, The Law-Growth Nexus: The Rule of Law and Economic Development; e David Trubek e Alvaro Santos (eds.), The New Law and Economic Development: A Critical Appraisal.

Neste ensaio, sugerimos que esses livros (ou, ao menos, alguns dos artigos neles reunidos) refletem uma insensibilidade para as ambiguidades que cercam a relação entre reforma jurídica e desenvolvimento. Mostramos que há um debate em andamento sobre questões fundamentais, tais como se o direito é um fator importante para determinar resultados sociais ou econômicos nas sociedades em desenvolvimento, tendo em vista a existência de métodos informais de controle social; se existem obstáculos econômicos, políticos ou culturais insuperáveis para uma reforma jurídica efetiva; bem como, supondo-se que uma reforma jurídica efetiva seja factível, que tipos de reformas são conducentes ao desenvolvimento e que tipos de atores devem implementá-las. Sustentamos que, embora existam alguns motivos para otimismo em relação ao impacto potencial das reformas jurídicas sobre o desenvolvimento, a literatura empírica pertinente é inconclusiva quanto a muitas questões importantes e aconselha cautela no que diz respeito ao investimento de recursos substanciais na promoção de reformas jurídicas nos países em desenvolvimento sem a realização de mais pesquisas que esclareçam essas questões.

\section{INTRODUÇÃO}

Thomas Carothers, no ensaio amplamente citado, "The Rule of Law Revival”, afirma:

Não podemos passar por um debate sobre política externa sem que alguém proponha o império do direito como solução para os males do mundo. De que modo a política americana em relação à China pode resolver o enigma de equilibrar direitos humanos e interesses econômicos? O estímulo ao império do direito (rule of law), sustentam alguns observadores, promove tanto os princípios quanto os lucros. O que fará com que a Rússia passe do capitalismo selvagem para uma economia de mercado mais ordeira? O desenvolvimento do império do direito, insistem muitos, é a chave. Como o México pode atravessar as traiçoeiras transições econômica, política e social? Dentro e fora do México, muitos respondem: estabelecer de uma vez para sempre o império do direito. ${ }^{1}$ 
Nas duas últimas décadas, coerentemente com a afirmação de Carothers, nações ocidentais e doadores privados despejaram bilhões de dólares na reforma do império do direito na América Latina, África subsaariana, Europa central e oriental e Ásia. ${ }^{2}$ Em outras palavras, nos países mais pobres do mundo, bilhões de dólares que poderiam ser destinados a projetos como programas de vacinação, educação primária, água e saneamento básico, vão para os bolsos dos juristas.

O amplamente noticiado ressurgimento do interesse em apoiar reformas jurídicas nos países em desenvolvimento reflete uma perspectiva fundamentalmente otimista sobre o papel do direito (e dos juristas) no desenvolvimento. Com efeito, os defensores dessas reformas são tipicamente otimistas em pelo menos três níveis. Primeiro, são otimistas ao acreditar que características específicas do sistema jurídico de um país desempenham um papel causal significativo na determinação de suas perspectivas de desenvolvimento; em suma, o direito é importante. Em segundo lugar, são otimistas quanto às possibilidades de uma reforma significativa. Em outras palavras, acreditam que os sistemas jurídicos mudam em resposta a esforços deliberados de reforma. Em terceiro lugar, são otimistas quanto à sua capacidade de identificar as reformas jurídicas que promoverão, em última análise, o desenvolvimento.

Embora o otimismo em relação à reforma jurídica pareça dominar o mundo da prática - e tenha efetivamente dominado nas duas últimas décadas -, no mundo das ideias, as concepções otimistas têm sofrido ataques de várias direções. O mais brando deles contesta o pressuposto de que os praticantes do direito e desenvolvimento são capazes de identificar e implementar as reformas jurídicas que promovem o desenvolvimento. Os ataques mais vigorosos contestam a noção de que os candidatos a reformadores podem ter esperanças razoáveis de efetuar mudanças jurídicas significativas, tendo em vista os obstáculos colocados por vários fatores históricos, econômicos, políticos ou culturais. O ponto de vista mais cético contesta a afirmação de que o direito desempenha um papel causal significativo no desenvolvimento. Essas contestações - que, por falar nisso, possuem paralelos diretos na literatura sobre a relação entre direito e mudança social nos Estados Unidos ${ }^{3}$-, são importantes porque, enquanto não forem respondidas, não poderemos saber se faz sentido continuar a dedicar recursos substanciais às reformas jurídicas nos países em desenvolvimento.

Esse problema, que Thomas Carothers chama de "o problema do conhecimento", faz do direito e desenvolvimento um campo maduro para a pesquisa acadêmica. ${ }^{4}$

O renascimento do interesse acadêmico pela relação entre direito e desenvolvimento reflete-se na publicação recente de três livros de proeminentes estudiosos americanos (em sua maioria) sobre o tema: Thomas Carothers (ed.), Promoting the Rule of Law Abroad: In Search of Knowledge ${ }^{5}$ Kenneth Dam, The Law-Growth Nexus: The Rule of Law and Economic Development ${ }^{6}$ e David Trubek e Alvaro Santos (eds.), The New Law and Economic Development:A Critical Appraisal. ${ }^{7}$ Tomadas em conjunto, essas obras 
representam o que há de melhor no pensamento atual dos juristas americanos sobre as relações entre reformas jurídicas e desenvolvimento.

Embora as colaborações publicadas nesses volumes representem décadas de experiência prática e reflexão acadêmica sobre reformas jurídicas em países em desenvolvimento, no fim das contas, elas são notavelmente inconclusivas. Nenhum dos autores representados nesses volumes parece estar muito otimista sobre a possibilidade de as reformas jurídicas promoverem o desenvolvimento (ao menos no início da trajetória do desenvolvimento). Porém, suas concepções vão do leve otimismo ao leve ceticismo e não fica imediatamente claro como resolver as diferenças de pontos de vista e as incertezas resultantes. Embora alguns dos colaboradores dos volumes editados por Trubek e Santos, e Carothers se refiram a uma nova ortodoxia ou consenso sobre o papel do direito no desenvolvimento, chama a atenção justamente a falta de consenso. ${ }^{8}$

Tendo em vista o que está em jogo para os habitantes dos países em desenvolvimento, para não mencionar os profissionais do direito, é preocupante o fracasso da academia em resolver as incertezas sobre a validade dos pressupostos básicos dos esforços para promover reformas jurídicas. Nosso objetivo principal ao escrever este artigo é descrever as dimensões do problema do conhecimento tal como refletido nos livros em questão, na esperança de estimular mais esforços para resolvê-lo.

Começamos delineando os vários tipos de afirmações otimistas que foram feitas sobre o papel das reformas jurídicas na promoção do desenvolvimento, tanto nos livros em questão como em outras publicações. Depois, tratamos dos motivos para ceticismo e suas implicações para a prática do direito e desenvolvimento. Examinamos sucessivamente as afirmações de que os reformadores jurídicos carecem da capacidade de identificar as reformas apropriadas, que eles devem superar obstáculos econômicos, políticos ou culturais potencialmente insuperáveis para efetuar reformas, ou ainda, que a reforma jurídica é irrelevante porque as alternativas informais ao direito têm importância prioritária como mecanismos de controle social. Sugerimos que a terceira e mais radical forma de ceticismo tem sido indevidamente negligenciada. Concluímos fazendo um exame das evidências empíricas que dizem respeito a esses debates, as direções que a pesquisa empírica futura deve tomar e o papel que os estudiosos do direito podem desempenhar nessa pesquisa.

\section{Os OTIMisTAS DO DIREITO}

Até mesmo entre os otimistas, há uma ampla variação de opiniões, algumas das quais são mutuamente incompatíveis, sobre o significado do desenvolvimento e os tipos de reformas jurídicas que provavelmente o promovem. Discutimos brevemente a primeira questão, mas, nesta seção, nos concentraremos mais na descrição das principais abordagens da segunda. Em nossa opinião, a maioria dos artigos incluídos nas obras em exame, ou tentam resolver as implicações dessas abordagens otimistas, ou as criticam. 


\section{I O QUE É DeSENVOLVIMENTO?}

Em certa medida, os desacordos sobre as reformas jurídicas apropriadas refletem desacordos mais fundamentais sobre os objetivos a serem alcançados pela reforma jurídica ou, em outras palavras, sobre o significado de desenvolvimento. Indícios desse desacordo podem ser observados nos livros em questão. Dam, seguindo uma linha adotada por muitos dos economistas, cujas obras ele examina, concentra-se na relação entre direito e desenvolvimento econômico, que ele parece, em geral, igualar a crescimento econômico. Em contraste, a maioria dos colaboradores do volume editado por Trubek e Santos e alguns dos que escreveram no livro editado por Carothers estão interessados nas implicações da reforma jurídica para um espectro mais amplo de resultados sociais, entre eles, o respeito aos direitos humanos, a igualdade de gênero e, de modo mais geral, a justiça distributiva. ${ }^{9}$ Em certa medida, essas diferenças de objetivos explicam a diferença entre os tipos de reformas jurídicas que os autores defendem: Dam enfatiza o direito empresarial, o direito comercial, o direito de propriedade e o setor financeiro, enquanto os colaboradores de Trubek e Santos, com destaque para Kerry Rittich, concentram-se nas funções reguladoras e redistributivas do Estado.

\section{I.2 O MOVimento Direito e Desenvolvimento}

$\mathrm{O}$ interesse intelectual pela relação entre direito e desenvolvimento tem uma longa história. ${ }^{10}$ Com efeito, pensadores dos séculos XVIII, XIX e início do XX, como Montesquieu, Maine e Weber, se interessaram profundamente por vários aspectos dessa relação no contexto europeu. Os pensadores europeus também se interessaram pelo papel desempenhado pelo direito durante o grande período de colonização dos séculos XVIII e XIX. ${ }^{11}$ Ademais, desde o século XIX, estudiosos dos países em desenvolvimento preocuparam-se muito com o papel que o direito poderia desempenhar no desenvolvimento social e econômico de seus países (embora, como destaca Scott Newton, essas vozes sejam frequentemente ignoradas no discurso acadêmico norteamericano). ${ }^{12}$ Boa parte dessa literatura é examinada na esclarecedora história intelectual com que Duncan Kennedy contribuiu para a coletânea de Trubek e Santos.

Não obstante o trabalho desses primeiros estudiosos, nos Estados Unidos ao menos, o ponto de vista otimista mais conhecido sobre a relação entre direito e desenvolvimento é aquele que surgiu na década de 1960 e é conhecido simplesmente como o "Movimento Direito e Desenvolvimento".

O pano de fundo intelectual desse movimento está no período do pós-guerra, que assistiu a um aumento no número de acadêmicos e formuladores de políticas interessados pelas nações pobres do mundo. Seguindo as pegadas do historiador econômico Walt W. Rostow, teóricos da década de 1950 e início da de 1960 sustentavam que o processo de desenvolvimento poderia ser visto como uma série de estágios sucessivos de crescimento econômico pelos quais todos os países deveriam passar. ${ }^{13}$ O que essa escola de pensamento propunha ficou conhecido como teoria da modernização. 
Os teóricos da modernização afirmavam que o subdesenvolvimento de uma sociedade era causado pelas características ou estruturas econômicas, políticas, sociais e culturais tradicionais (em oposição a modernas) e se refletia nelas. Para progredirem, as sociedades subdesenvolvidas teriam de passar pelo mesmo processo de evolução do tradicionalismo para a modernidade que as sociedades mais desenvolvidas haviam experimentado anteriormente. Porém, enquanto o ímpeto de modernização nos países agora desenvolvidos resultara de mudanças endógenas, a transformação das nações em desenvolvimento resultaria principalmente de estímulos exógenos. Ou seja, a modernização do Terceiro Mundo seria realizada pela difusão do capital, das instituições e dos valores do Primeiro Mundo. ${ }^{14}$

Mais especificamente, isso implicaria a emergência de um sistema de livre mercado, do império do direito, de uma política multipartidária, da racionalização da autoridade e do crescimento da burocracia e da proteção dos direitos humanos e das liberdades básicas. Presumia-se que a ocidentalização, a industrialização e o crescimento econômico gerariam as pré-condições para a evolução de uma maior igualdade social e, em consequência, o surgimento de instituições democráticas estáveis e do Estado de bem-estar social. Durante esse processo, o Estado serviria de agente primário da mudança social.

Com base na teoria da modernização, a primeira onda de teóricos do direito e desenvolvimento que surgiu na década de 1960 presumia que a difusão do direito ocidental para o Terceiro Mundo ajudaria em sua modernização. Com efeito, acreditava-se que o direito moderno era o "pré-requisito funcional de uma economia industrial". ${ }^{15}$ Influenciada por Weber, uma forte concepção instrumentalista do direito estava na base dessa visão da relação entre direito e desenvolvimento. Tal como definida por Burg, essa concepção "considera o direito uma força que pode ser moldada e manipulada para alterar o comportamento humano e alcançar o desenvolvimento". ${ }^{16}$ Ela "concentra-se sobretudo nas normas substantivas do direito, espera do Estado a promulgação dessas normas e reserva para a profissão jurídica um papel proeminente na formulação delas". ${ }^{17}$ Essa concepção do direito como um instrumento de desenvolvimento, e não apenas de resposta a ele, bem como a visão do jurista como um "engenheiro social" estava totalmente de acordo com a "necessidade percebida de mudanças dirigidas e rápidas” que subjazia à noção de desenvolvimento da escola da modernização. ${ }^{18}$

Armado com o modelo instrumental do papel do direito no desenvolvimento, o movimento adotou uma abordagem de cima para baixo. Enfatizava a reforma da educação e da profissão jurídica e, em menor medida, a reforma das normas jurídicas formais. Pressupunha-se que os juristas treinados para usar o direito como instrumento de mudança promoveriam os objetivos desenvolvimentistas do Estado. ${ }^{19}$ Presumia-se que a reforma do ensino do direito e da advocacia estimularia outras formas de modernização, inclusive o surgimento de outras instituições inerentes a um sistema jurídico moderno eficaz, tais como aquelas responsáveis por administrar e 
aplicar as normas jurídicas. Havia algum reconhecimento de que poderia haver um "hiato" ou falta de correspondência perfeita entre o "direito nos livros" e o "direito em ação". Nesses casos, a resposta dos teóricos do direito e desenvolvimento ainda era a de confiar na reforma do ensino do direito e em uma melhor "penetração", definida por Friedman como "o grau em que uma norma, um código ou uma lei se enraíza numa população". ${ }^{20} \mathrm{~A}$ chave para eliminar o hiato e melhorar a penetração era a melhor comunicação do direito com a população. ${ }^{21}$

Para o bem ou para o mal, elementos desses conceitos de direito e desenvolvimento sobrevivem no pensamento contemporâneo. Por exemplo, em sua colaboração para o volume organizado por Carothers, Wade Channell argumenta que as concepções que animam os programas atuais de reforma jurídica e judicial do Banco Mundial não são somente similares àquelas endossadas pelo movimento original de direito e desenvolvimento, mas também igualmente falhas. ${ }^{22} \mathrm{Em}$ tom mais positivo, a contribuição otimista de Stephen Golub ao volume editado por Carothers (a coletânea inclui também um ensaio dele que é muito mais cético) recomenda um programa de reformas jurídicas que parece ter uma abordagem muito semelhante à de alguns dos programas associados ao movimento Direito e Desenvolvimento. ${ }^{23}$ A "alternativa de empoderamento jurídico" de Golub enfatiza a reforma do ensino para incluir a oportunidade de os estudantes de direito ajudarem os pobres mediante clínicas jurídicas e outros programas, a alteração da estrutura da profissão jurídica a fim de permitir que "para-advogados" desempenhem um papel maior no fornecimento de serviços jurídicos e a comunicação de informações jurídicas diretamente ao povo. ${ }^{24}$

\section{I.3 A NOVA ECONOMia Institucional}

No mundo acadêmico do direito americano, o interesse pelos sistemas jurídicos dos países em desenvolvimento declinou significativamente em meados da década de 1970 (por motivos que examinaremos mais adiante). ${ }^{25}$ Logo depois, no entanto, os economistas redescobriram o tema. O interesse deles coincidiu com o surgimento da assim chamada Nova Economia Institucional, que considera o projeto e o funcionamento das instituições do setor público e das organizações do setor privado que interagem com essas instituições fatores determinantes essenciais das perspectivas de desenvolvimento dos países, por meio dos incentivos que criam para participar em atividades socialmente produtivas ou improdutivas. ${ }^{26}$

Os proponentes desse conceito fizeram alegações extremamente audaciosas sobre o impacto potencialmente benéfico das reformas jurídicas. Por exemplo, em seu influente livro The Other Path, Hernando de Soto faz afirmações como: "O sistema jurídico pode ser a principal explicação para a diferença de desenvolvimento que existe entre países industrializados e aqueles que não o são". ${ }^{27} \mathrm{Ou}$ : "O desenvolvimento só é possível se existem instituições jurídicas eficientes à disposição de todos 
os cidadãos". ${ }^{28} \mathrm{Ou}$ ainda: "O direito é o instrumento mais útil e deliberado de mudança disponível para o povo”. ${ }^{29}$

Afirmações semelhantes, embora, talvez, um pouco menos extravagantes, podem ser encontradas em documentos produzidos por agências influentes, como o Banco Mundial. 30

O livro de Kenneth Dam é explicitamente dedicado a descrever as implicações da nova economia institucional para a reforma jurídica. ${ }^{31}$ Muitas dessas implicações se parecem com aquelas apresentadas pelos teóricos da modernização numa época anterior. ${ }^{32}$ Em termos de direito substantivo, desse ponto de vista, as prioridades essenciais devem estar ligadas a direitos de propriedade bem definidos e alienáveis; um sistema formal de direito contratual que torne mais fácil a contratação impessoal; um regime de direito empresarial que simplifique a função de investimento de capital por meio da facilitação da incorporação e responsabilidade limitada de pequenas e médias empresas e minimize os custos de agência enfrentados pelos acionistas em firmas com acionistas majoritários em geral no caso de empresas não administradas por donos ou por acionistas minoritários em firmas com acionistas majoritários; um sistema de garantia de empréstimos que torne fácil para os credores tomar uma ampla variedade de ativos como colateral, identificar reivindicações em competição por esses ativos, e tomar e vender os ativos em caso de não pagamento; um regime de falência que induza a saída de empresas ineficientes e a redistribuição de seus ativos para usos de maior valor; e um regime tributário não punitivo e sem distorções. A fim de garantir a promulgação, a execução e a administração dessas leis substantivas, estão entre as prioridades projetar instituições legislativas que sejam transparentes e estáveis em seu compromisso com as normas jurídicas básicas e incluir os investidores perante os quais respondem, e instituições administrativas e de aplicação da lei que sejam competentes, incorruptas, livres de influência política indevida, de procedimentos transparentes e que contenham efetivos recursos.

Nem todos os proponentes da Nova Economia Institucional endossam a ideia de que os países em desenvolvimento estariam mais bem servidos adotando os modelos jurídicos ocidentais. ${ }^{33}$ Por exemplo, teóricos como Robert Cooter e Hernando de Soto sustentam que é, em geral, útil para as normas jurídicas formais imitar o conteúdo das normas não legais locais, de modo a assegurar que os mecanismos informais associados a essas normas trabalhem no sentido de aumentar a potência das normas legais. ${ }^{34}$ Em um viés um pouco distinto, Katharina Pistor e seus coautores argumentaram que é difícil transplantar as normas jurídicas ocidentais (ou quaisquer outras normas) de sociedades desenvolvidas para as em desenvolvimento porque tais normas são, com frequência, expressas em termos de referências a outras normas ou conceitos jurídicos; desse modo, são difíceis de entender para os membros da sociedade que os recebe sem que tenham uma boa compreensão de grandes porções do sistema jurídico de onde originam-se. 35 
Como vários outros estudiosos, Pistor et al. sustentam que a força das normas jurídicas depende muito de serem bem entendidas por membros da sociedade e agentes do Estado. Por sua vez, Dam simpatiza com a opinião de que um modelo único talvez não sirva para todos. Ele dedica uma quantidade significativa de espaço para rebater as alegações de que um determinado conjunto de instituições jurídicas ocidentais - a saber, aquelas associadas ao common law, em oposição ao direito civil é inerentemente superior. ${ }^{36}$ Ele observa também que, em geral, no que diz respeito a países em desenvolvimento transplantarem instituições jurídicas dos países desenvolvidos, “... nem mesmo as soluções de melhor prática do mundo funcionarão se a sociedade resistir a elas ou ignorá-las". ${ }^{37}$

\section{I.4 O NOvo CONSTITUCIONALISMO}

Do ponto de vista empírico, uma boa parte do ressurgimento do interesse pelo direito nos países em desenvolvimento envolve um interesse no direito constitucional desses países. ${ }^{38}$ Mais de 56\% dos 188 Estados-membros das Nações Unidas fizeram importantes emendas às suas constituições na década decorrida entre 1989 e 1999, e desses Estados, pelo menos $70 \%$ adotaram constituições inteiramente novas. Ao menos um quarto de todos os Estados membros da ONU introduziu leis de direitos e alguma forma de revisão constitucional em seus regimes constitucionais durante esse período. Em consequência, pelo menos 92 países, ou aproximadamente 50\% dos Estados membros, incorporaram leis de direitos, direitos fundamentais ou alguma forma de direitos individuais e/ou coletivos aos seus regimes constitucionais. Antes de 1989, cerca de dez países tinham sistemas efetivos de revisão constitucional em que um tribunal constitucional ou os tribunais em geral declaravam que uma lei proposta ou promulgada era contrária à constituição do Estado. Dez anos depois, pelo menos 70 Estados - cerca de 38\% de todos os Estados membros da ONU - haviam adotado alguma forma de revisão constitucional. ${ }^{39}$ Do mesmo modo, muitos países ratificaram vários tratados e convenções internacionais sobre direitos humanos. ${ }^{40}$

Em certa medida, a ampla atenção dada à reforma constitucional pode ser justificada sem recorrer a concepções instrumentais do papel do direito no desenvolvimento. Em alguns pontos de vista, as constituições que encarnam proteções aos direitos humanos, democracia, etc., são fins em si mesmas, manifestações dos compromissos morais de uma sociedade. ${ }^{41}$ De outra perspectiva, essas reformas constitucionais são apenas compromissos caros que as elites políticas assumem a fim de sinalizar aos investidores a força de seu compromisso com o império do direito e a liberalização econômica. ${ }^{42}$

A reforma constitucional também pode ser justificada em termos mais diretamente instrumentais. Não é incomum justificá-la como um meio de assegurar a existência de instituições capazes de promulgar e impor normas substantivas que levarão, em última análise, à paz e à prosperidade. Até mesmo Kenneth Dam, que 
dedica o grosso de seu livro a analisar a relação entre várias áreas substantivas de direito privado - empresarial e comercial, de propriedade, etc. - e o desenvolvimento econômico, acaba por sustentar que o direito público é mais importante que o privado para o crescimento econômico. ${ }^{43}$ Em termos gerais, o otimismo em relação ao potencial instrumental das normas constitucionais enfoca e endossa os arranjos constitucionais que exibem três atributos: democracia, separação de poderes e liberdade de imprensa.

\section{I.4. I Democracia}

Muitos teóricos do desenvolvimento assumem a posição de que a democracia - definida aqui de forma estrita pela seleção de líderes políticos em eleições livres, justas e competitivas - é, em geral, conducente ao desenvolvimento. ${ }^{44}$ Alguns desses teóricos concentram-se na conexão entre democracia e medidas ortodoxas de desenvolvimento, tais como crescimento econômico, níveis de educação e mortalidade infantil. ${ }^{45}$ Porém, outros sustentam que existe uma relação positiva entre democracia e definições mais amplas de desenvolvimento. Por exemplo, é famosa a afirmação de Amartya Sen de que não se trata de mera coincidência o fato de nunca ter havido uma epidemia de fome numa democracia multipartidária vigente. ${ }^{46}$ Do mesmo modo, a partir de Immanuel Kant, vários cientistas políticos sustentaram que é altamente improvável que democracias entrem em guerra umas contra as outras. ${ }^{47}$

Muitos desses pensadores baseiam-se na ideia de que as democracias geram incentivos relativamente fortes para que os líderes políticos promovam o desenvolvimento. ${ }^{48}$ Por exemplo, em Power and Prosperity, ${ }^{49}$ Olson distingue três regimes políticos básicos: bandidos errantes, bandidos estacionários e democracias, supondo que, em todos os casos, os líderes políticos são motivados pelo interesse pessoal. Os bandidos errantes (exemplo recente podem ser os grupos rebeldes em Serra Leoa, Sudão, Angola e Congo, que saqueiam os recursos naturais dos países) têm taxas de desconto de tempo extremamente altas devido à sua insegurança no poder e explorarão as populações locais até o limite de confiscar toda a sua riqueza. ${ }^{50}$ Em contraste, os bandidos estacionários controlam totalmente um determinado território e, dependendo de sua segurança no cargo e, por conseguinte, das taxas de desconto de tempo, podem ter um incentivo para adotar medidas menos confiscatórias. A estratégia de adotar quantidades de confisco inferiores ao máximo cria incentivos para que a cidadania seja produtiva em períodos de tempo futuros e, assim, pode aumentar as receitas totais de um déspota com uma taxa de desconto relativamente baixa. ${ }^{51}$ Os líderes democráticos, no entanto, têm incentivos mais fortes para promover concepções mais amplas do interesse social e concomitantes leis e instituições jurídicas que os bandidos errantes ou estacionários. De acordo com Olson, isso ocorre porque, ao contrário dos governantes autocráticos, os democraticamente eleitos podem, com frequência, prever o retorno ao poder em data futura, 
após serem derrotados em eleição. Essa perspectiva pode induzi-los a dar um valor relativamente alto à melhoria do bem-estar futuro de seus cidadãos. ${ }^{52}$

Vários outros argumentos apresentados a favor da democracia não se baseiam em reivindicações de efeitos de incentivo. Por exemplo, Dani Rodrik sustenta que as instituições políticas participativas são as "metainstituições" mais confiáveis de um ponto de vista desenvolvimentista, porque são as mais adequadas para extrair e agregar o conhecimento local exigido para desenvolver outras normas e instituições. Na esteira de pensadores como John Stuart Mill e Immanuel Kant, Rodrik afirma, também, que os processos deliberativos que costumam estar associados à democracia tendem a fazer com que as pessoas tenham mais espírito público e disposição para fazer acordos. Ele escora esses argumentos com provas empíricas de que as democracias exibem qualidades superiores às das autocracias na gestão dos conflitos sociais e no estabelecimento de acordos sociais para tratar do ajuste a choques macroeconômicos. ${ }^{53}$

\section{I.4.2 SeParaç̃̃o DE PODERES}

Deixando de lado o debate em torno de autocracia e democracia, outra importante linhagem de literatura, cujas origens podem ser remontadas ao Espírito das leis, de Montesquieu, ${ }^{54}$ enfatiza o papel dos freios e contrapesos constitucionais e políticos como métodos de obrigar o Estado a agir em defesa do interesse social geral, em vez de defender os interesses estreitos de pequenas coalizões distributivas. ${ }^{55}$ Muitos estudiosos asseveram que a separação constitucional dos poderes baseia-se fundamentalmente na existência de um juiz confiável, isto é, de um judiciário independente para impor a alocação prescrita de poderes e inspirar respeito por suas decisões, com frequência, de agências do próprio Estado. Infelizmente, a definição exata de independência judicial é uma questão em debate. ${ }^{56}$

A literatura identificou várias maneiras pelas quais a separação de poderes ajuda a aumentar a probabilidade da promulgação de leis socialmente benéficas, mas três argumentos se destacam. Primeiro, o de que a separação de poderes aumenta o custo dos grupos de interesse de "capturar" as instituições políticas ou judiciárias. A intuição básica por trás desse argumento é que quanto maior o número de instituições um ator ou grupo de atores tiver de lidar para promover seus interesses, mais provável será que os custos de transação e o comportamento estratégico evitarão a conclusão de um acordo.

Um segundo argumento usado comumente para justificar a separação dos poderes é que ela torna difícil para os governos descumprir de forma oportunista compromissos anteriores. Por exemplo, North e Weingast observam que após a Revolução Gloriosa na Inglaterra, os poderes do parlamento aumentaram muito, mas a monarquia não foi completamente abolida. ${ }^{57} \mathrm{~A}$ criação de um equilíbrio de poder entre as instituições serviu para aumentar a previsibilidade das políticas governamentais: "Aumentar o número de atores com poder de veto implicava que um conjunto 
maior de eleitores podia se proteger contra o assalto político, reduzindo assim de modo marcante as circunstâncias em que o comportamento oportunista do governo poderia ocorrer". ${ }^{58}$ Em uma variante desse argumento, Stephenson, desenvolvendo uma sugestão anterior de Ramseyer, sugere que a revisão por um judiciário independente pode ajudar a fazer com que rivais políticos avessos ao risco cumpram compromissos assumidos entre eles e se comportem de modo moderado no poder. ${ }^{59}$

Por fim, o terceiro argumento a favor da separação dos poderes é que ela tende a promover a competição entre diferentes instituições. Em algumas circunstâncias, o desempenho de uma instituição serve de medida para o desempenho de outras. A competição pode ser horizontal, como no caso da que ocorre entre os poderes executivo, legislativo e judiciário, ou vertical, como entre níveis nacionais e subnacionais de governo. ${ }^{60}$

Por exemplo, Weingast defende as virtudes do que chama de "federalismo preservador do mercado". Os principais atributos de um sistema federal de preservação do mercado são que a autoridade primária sobre a economia fica na mão dos governos regionais, em vez de com o governo central, mas os governos regionais são impedidos a erguer barreiras ao livre movimento de mão-de-obra e bens e enfrentam uma dura restrição orçamentária, de tal modo que não podem imprimir dinheiro e não têm acesso a crédito ilimitado. ${ }^{61}$ De acordo com Weingast, dentro de um sistema federal de preservação do mercado, as unidades de governo regional competem por capital e trabalho implementando as normas econômicas mais eficientes. Enquanto isso, o governo central não tem autoridade para acomodar os interesses econômicos que foram deslocados e que prometem apoio político em troca da intervenção para deter ou reverter as mudanças que acompanham o crescimento econômico. ${ }^{62}$

Kenneth Dam aceita os argumentos em favor da separação dos poderes e a importância de um poder judiciário eficiente e independente, mas ressalta que esses conceitos parecem significar coisas diferentes dependendo do país ou estão, pelo menos, encarnados em distintas instituições jurídicas. ${ }^{63}$ Inglaterra, França e Estados Unidos atribuem quantidades de poder muito diferentes ao legislativo em relação a outros ramos do governo. ${ }^{64}$ Ele mostra também que esses e outros países diferem consideravelmente em termos dos mecanismos que governam as nomeações e as rescisões judiciais, os critérios para nomeação e promoção no judiciário, e a indenização judicial. ${ }^{65}$ Além disso, essas questões são todas temas de controvérsia nas democracias desenvolvidas do Ocidente e apresentam problemas ainda mais sérios em muitos países em desenvolvimento com tradições débeis de democracia e liberdades civis, e poucos profissionais do direito de alto gabarito e sem filiações políticas.

I.4.3 LIBERDADE DE IMPRENSA

Outro corpo de literatura enfatiza a importância do desenvolvimento de uma imprensa livre e competitiva - ou seja, independente da influência do governo -, em 
particular como freio para o abuso de poder das autoridades. ${ }^{66}$ Por exemplo, Amartya Sen sustentou que as epidemias de fome não acontecem em sociedades com acesso a uma imprensa livre porque uma população consciente pode utilizar os meios de comunicação para pressionar o governo a mudar as políticas que tratam do problema em questão. ${ }^{67} \mathrm{Em}$ termos mais gerais, ele sugere que uma estrutura institucional que apoie a liberdade de manifestação e sua busca através da mídia pode provocar outras mudanças institucionais ao chamar a atenção da população e, portanto, das autoridades públicas, para questões controvertidas que as autoridades precisam enfrentar. ${ }^{68}$

Em linha similar, outros estudiosos sugeriram que uma imprensa livre pode desempenhar um papel importante no controle do abuso de poder por autoridades estatais. A teoria é que, se a imprensa é livre e competitiva, os jornalistas terão um incentivo para revelar e relatar casos de abuso. Brunetti e Weder sustentam que essa teoria é confirmada por análises de regressão transnacionais da relação entre medidas de liberdade de imprensa e corrupção, embora eles não especifiquem que tipos de corrupção são mais afetados. ${ }^{69} \mathrm{~A}$ liberdade de imprensa pode também impedir o abuso de poder ao limitar a capacidade do Estado de manipular os meios de comunicação. Por exemplo, em algumas sociedades existe a preocupação com o fato de a mídia controlada pelo Estado ser usada para promover a inimizade em relação a minorias étnicas. Uma imprensa livre pode ser menos vulnerável a esse tipo de manipulação. ${ }^{70}$

\section{I.5 OS INTERNACIONALISTAS}

Os livros de Carothers e Dam centram a atenção nas instituições jurídicas nacionais e seus efeitos sobre o bem-estar dos habitantes de países em desenvolvimento. Porém, como a maioria dos colaboradores da coletânea de Trubek e Santos reconhece, muitos formuladores de políticas e estudiosos preocupados em melhorar a situação desses países e de seus habitantes concentram-se nas instituições jurídicas internacionais. Nas décadas de 1960 e 1970, o foco da atenção era a ONU, e os apelos pela criação de uma "nova Ordem Econômica Mundial" resultaram na aprovação de várias resoluções históricas na Assembleia Geral das Nações Unidas. ${ }^{71}$ Mais recentemente, a atenção mudou para outros traços proeminentes do sistema jurídico internacional, tais como as leis internacionais de direitos humanos, a Organização Mundial do Comércio, a Convenção Anti-suborno da Organização para a Cooperação e Desenvolvimento Econômico (OCDE) e os tratados bilaterais de investimento.

O otimismo em relação ao papel das reformas do direito econômico internacional baseia-se, em parte, em seus efeitos potenciais sobre o comércio e o investimento internacionais que, por sua vez, influenciam os preços enfrentados pelos consumidores locais, as oportunidades para os produtores locais comercializarem seus produtos, e incentivos para que esses produtores inovem. Esse tipo de análise sustenta claramente os apelos por reformas de provisões da OMC, que governam assuntos como comércio 
internacional de produtos agrícolas e comércio de serviços de trabalhadores de baixa qualificação, bem como certos aspectos dos tratados bilaterais de investimento.

$\mathrm{O}$ otimismo quanto às reformas jurídicas no nível internacional também se baseia, em parte, nos efeitos potenciais dessas reformas sobre as instituições jurídicas nacionais. ${ }^{72}$ Para começar, alguns aspectos do regime jurídico internacional regulam diretamente o conteúdo do direito nacional. Por exemplo, vários aspectos dos acordos da OMC proíbem certos tipos de arranjos jurídicos internos com base na teoria de que constituem barreiras disfarçadas ao comércio. Porém, o regime internacional também pode moldar indiretamente as instituições jurídicas nacionais, ao alterar a paisagem política interna. Por exemplo, as reformas que reduzem as barreiras ao comércio podem fazer com que os setores da economia orientados para a exportação se expandam e aumentem seu poder político. Eles podem então usar esse poder para exigir reformas jurídicas que promovam os próprios interesses econômicos e, possivelmente, de outros membros da sociedade.

Por outro lado, Brunetti e Weder argumentam que as reformas que liberalizam o fluxo internacional de bens, capitais e trabalho podem provocar reformas jurídicas internas ao aumentar as oportunidades dos membros da sociedade de sair e de exercer sua voz. ${ }^{73}$ Eles sustentam que "a abertura aumenta a mobilidade de fatores livres e sem compromisso", apresentando uma ameaça crível de saída. Portanto, os governos preocupados com a manutenção de sua base tributária teriam incentivos para melhorar os serviços públicos básicos. ${ }^{74}$ Eles afirmam também que, em economias mais abertas, os indivíduos são expostos com mais frequência aos sistemas políticos de outras nações "e aprendem a partir da observação como é benéfico para os negócios um império de direito vigente". ${ }^{75}$ Essas observações propiciam aos indivíduos marcos para avaliar a qualidade dos serviços de seus governos, pressionando-os a melhorar os que apresentam deficiências.

\section{I.6 OS OTIMISTAS DO IMPÉRIO DO DIREITO}

A maioria das teorias examinadas até agora enfatiza a relação entre um aspecto do sistema jurídico - direito público ou privado, direito internacional ou nacional, etc. - e o desenvolvimento. Porém, muitos otimistas assumem um ponto de vista mais holístico sobre a questão. Como a epígrafe de Carothers sugere, esses otimistas enfocam o grau em que o sistema jurídico em geral manifesta respeito pelo "império do direito", em vez de tratarem dos atributos de qualquer componente isolado do sistema como determinante do desenvolvimento. ${ }^{76}$

Para alguns teóricos, o império do direito indica um conjunto de características intrinsecamente valiosas de um sistema jurídico, antes um fim do que um meio do desenvolvimento. Para outros, no entanto, o foco no império do direito se justifica pela noção de que o direito e as instituições jurídicas desempenham funções sociais fundamentais e que eles devem assumir uma determinada forma a fim de cumpri-las. 
O artigo de Rachel Kleinfeld, na coletânea de Carothers, constitui uma afirmação exemplar desse ponto de vista. ${ }^{77}$ Ao assumir essa posição, ela se baseia em ideias que estão profundamente arraigadas na teoria do direito ocidental moderno. ${ }^{78} \mathrm{Um}$ dos principais expoentes desse conceito foi Lon Fuller. Em uma de suas obras mais famosas, ele identificou oito desiderata distintos ao se projetar um sistema jurídico. Segundo essa lista, em forma resumida, uma lei deveria: (1) ser de aplicação geral; (2) ser divulgada ou, ao menos, estar disponível de antemão às partes afetadas; (3) ser de aplicação possível; (4) ser compreensível; (5) ser coerente (isto é, não contraditória); (6) não exigir conduta além dos poderes da parte afetada; (7) não estar sujeita a mudanças frequentes; (8) e refletir congruência entre as normas tal como anunciadas e sua administração efetiva. De forma um tanto controversa, Fuller sustentava que um sistema jurídico que não satisfizesse esses desiderata não seria apenas ruim, como não poderia ser chamado de forma alguma de sistema jurídico. ${ }^{79}$ Parece que ele assumia a posição de que um sistema jurídico que não cumprisse algumas ou todas essas condições não seria capaz de servir a qualquer propósito social útil (em parte porque seria improvável que obtivesse a cooperação voluntária dos cidadãos), e de que os objetivos sociais do direito são cruciais. ${ }^{80}$

Em tempos mais recentes, entrou na moda referir-se sucintamente às virtudes fundamentais dos sistemas jurídicos como manifestações do “império do direito". Em um famoso ensaio, Joseph Raz sugeriu que a ideia básica subjacente ao império do direito pode ser derivada começando-se da simples premissa de que o direito deve ser capaz de orientar o comportamento de seus súditos. A partir dessa ideia básica, Raz produziu uma lista de princípios que servem como sinais da existência do império do direito. Sua lista coincide em parte com a de Lon Fuller, a tal ponto que inclui os princípios de que "todas as leis devem ser de aplicação possível, abertas e claras", e "devem ser relativamente estáveis", bem como "a criação de determinadas leis [...] deve ser orientada por regras abertas, estáveis, claras e gerais”. Porém, o traço mais interessante da lista de Raz é que ela inclui também princípios que se referem tanto às instituições que aplicam as normas jurídicas quanto às próprias normas legais. Com efeito, esses princípios de desenho institucional constituem cinco dos oito itens de sua lista. Especificamente, Raz diz que "a independência do judiciário deve ser garantida", "os princípios da justiça natural devem ser observados", "os tribunais devem ter poderes de revisão sobre a implementação dos outros princípios" e "os tribunais devem ser de fácil acesso". ${ }^{81}$ Tal como Fuller, Raz sugere que a conformidade ao império do direito é "virtualmente sempre" de valor instrumental na medida em que permite que o sistema jurídico desempenhe funções sociais úteis. ${ }^{82}$

Tratando explicitamente dos países em desenvolvimento, Brian Tamanaha também defende o ponto de vista de que o império do direito tem valor instrumental. ${ }^{83}$ Porém, sua versão "minimalista" do império do direito "exigiria apenas que o governo se submeta às regras promulgadas pela autoridade política e trate seus cidadãos 
com dignidade humana básica, e que exista acesso a um órgão decisório ou judiciário justo e neutro (na medida do possível) para ouvir as reivindicações ou resolver disputas". ${ }^{84}$ De acordo com Tamanaha, o império do direito assim definido desempenha um papel importante na proteção dos indivíduos contra governos autoritários opressivos ou desonestos.

Um traço interessante das análises de Fuller, Raz, Tamanaha e Kleinfeld é sua abstração dos detalhes legais e institucionais. Os quatro deixam razoavelmente claro que, do ponto de vista deles, vários arranjos jurídicos e institucionais são compatíveis com a maioria de suas prescrições. Por exemplo, de sete de seus oito desiderata, Fuller diz que "[...] o máximo que podemos esperar das constituições e dos tribunais é que eles nos salvem do abismo; não podemos esperar que estabeleçam muitos passos compulsórios na direção de uma realização verdadeiramente significativa". ${ }^{85} \mathrm{Na}$ mesma linha, Raz deixa claro que "a validade e a importância de muitos dos princípios que podem ser derivados da ideia básica do império do direito dependem das circunstâncias particulares de diferentes sociedades". Ele menciona também que "[os princípios] devem ser constantemente interpretados à luz da ideia básica”. Quanto a Tamanaha, ele se esforça para enfatizar que sua concepção minimalista do império do direito é "compatível com muitos arranjos socioculturais". 86 Do mesmo modo, Kleinfeld declara que "os objetivos finais do império do direito podem ser alcançados mesmo quando as instituições variam amplamente". 87

O fato de Fuller, Raz, Tamanaha e Kleinfeld tentarem formular proposições universais sobre as características de sistemas jurídicos socialmente desejáveis os situa perfeitamente no campo dos otimistas do direito. Isso indica que otimistas que também afirmam os méritos de instituições jurídicas específicas, como, por exemplo, Kenneth Dam, endossariam a alegação de que o império do direito é importante para o desenvolvimento. ${ }^{88}$ Porém, a relutância desses teóricos em endossar meios específicos de alcançar a excelência jurídica os coloca à parte de muitos otimistas do direito e pode fazer com que o trabalho deles atraia alguns dos céticos cujas concepções examinaremos a seguir. ${ }^{89}$

\section{OS CÉTICOS DO DIREITO}

\section{I O MARCO HISTÓRICO DA CRÍTICA}

A primeira onda de otimismo em relação ao direito e desenvolvimento no período do pós-guerra teve vida curta: ela mal começara em meados da década de 1960 e já em 1974, Trubek e Galanter - duas figuras fundadoras do campo -, anunciavam seu óbito no muito citado artigo "Acadêmicos auto-alienados.... .90 Em certa medida, eles remontam o declínio do movimento a experiências exclusivamente americanas com o movimento dos direitos civis e a guerra do Vietnã. Essas experiências levaram a uma 
consciência da discrepância entre os ideais americanos e a realidade do sistema jurídico do país. Em outras palavras, à medida que começavam a questionar seus ideais em casa, os americanos começavam também a questionar seu valor como modelo para outros países. Eles notaram também o ceticismo em relação aos motivos do governo dos Estados Unidos e seus colaboradores locais em muitos países em desenvolvimento durante o período da guerra fria. Porém, a razão mais fundamental para o declínio do movimento Direito e Desenvolvimento era o fato de ser amplamente percebido como um fracasso na melhoria apreciável da situação da maioria dos países em desenvolvimento. Por sua vez, essa avaliação desfavorável influenciou os patrocinadores de iniciativas de direito e desenvolvimento a reduzir ou retirar o apoio aos programas dessa área. ${ }^{91}$

De acordo com o artigo crucial de Trubek e Galanter, a ideia de que o legalismo liberal americano podia ser transplantado com sucesso para países em desenvolvimento estava completamente equivocada. Consideravam essa ideia "etnocêntrica e ingênua”, pois as precondições para o êxito da implementação do modelo jurídico liberal contrastavam fortemente com a realidade dos países em desenvolvimento. Afirmavam eles:

\footnotetext{
Empiricamente, o modelo presume um pluralismo social e político, ao passo que na maior parte do Terceiro Mundo, encontramos estratificação social e clivagem de classe justapostas a sistemas políticos autoritários ou totalitários. O modelo presume que as instituições estatais são o lugar principal do controle social, ao passo que, em boa parte do Terceiro Mundo, o domínio da tribo, do clã e da comunidade local é muito mais forte do que o do Estadonação. O modelo presume que as normas refletem os interesses da vasta maioria dos cidadãos e, ao mesmo tempo, são normalmente internalizadas por eles, enquanto em muitos países em desenvolvimento as normas são impostas a muitos por poucos e são frequentemente mais honradas na infração do que na observância. O modelo presume que os tribunais são atores centrais no controle social e que são relativamente autônomos em relação aos interesses políticos, tribais, religiosos ou de classe. Contudo, em muitos países, os tribunais não são muito independentes nem muito importantes. ${ }^{92}$
}

Devido à divergência entre as condições nos países em desenvolvimento e aquelas existentes nas nações desenvolvidas, a reforma das instituições jurídicas tinha pouca ou nenhuma influência sobre as condições sociais ou econômicas dos países do Terceiro Mundo. Isso se devia, em parte, ao fato de o sistema jurídico formal - o foco principal do legalismo liberal -, não ser acessível à maioria da população em grande parte dos países em desenvolvimento. A esse respeito, o primeiro movimento Direito e Desenvolvimento poderia ser acusado de dar pouca atenção às leis consuetudinárias e outras instituições jurídicas informais. ${ }^{93}$ Pior ainda, na medida 
em que enfatizava o potencial instrumental do direito, o programa de direito e desenvolvimento tinha o efeito de reforçar desigualdades perniciosas e permitir que as instituições jurídicas servissem de instrumentos de dominação nas sociedades em desenvolvimento. Ademais, o desenvolvimento de capacidades instrumentais dos juristas locais pode ter, na verdade, reforçado as desigualdades sociais e econômicas ao elevar o custo dos serviços jurídicos e reduzir a participação na tomada de decisões por meio da formalização da tomada de decisão jurídica. Uma melhoria das capacidades instrumentais dos advogados poderia conduzir a uma resistência mais efetiva das elites em relação aos esforços de desenvolvimento; elas contratariam gente do grupo conservador de profissionais da lei para esse fim. ${ }^{94}$

A abordagem cética do direito e desenvolvimento apresentada em "Acadêmicos auto-alienados..." pode ser considerada uma síntese de várias escolas díspares de pensamento, como pluralismo jurídico, materialismo histórico, teoria da dependência, estudos jurídicos críticos e determinismo cultural. A síntese que Trubek e Galanter criaram continua a ser extremamente influente e, sob muitos aspectos, foi rearticulada nos artigos coligidos e editados por Carothers e por Trubek e Santos. Porém, é importante reconhecer que seus componentes intelectuais subjacentes, em muitos casos, eram preexistentes à publicação do famoso artigo e continuaram a se desenvolver de forma independente. No interesse da clareza analítica, é útil distinguir esses componentes. É particularmente importante não esquecer que a crítica de Trubek e Galanter abrange ao menos três formas distintas de ceticismo, a saber: (1) ceticismo quanto à capacidade dos atores que se engajaram na reforma jurídica, até agora, de identificar e implementar as reformas apropriadas; (2) ceticismo quanto ao sistema jurídico ser um traço da sociedade manipulável verdadeira e independentemente; (3) e, o que talvez seja o mais importante, ceticismo quanto à existência de alguma relação causal entre reformas jurídicas e desenvolvimento.

\subsection{Problemas de implementação}

Boa parte do debate atual sobre direito e desenvolvimento não é sobre a viabilidade da reforma jurídica ou se ela tem o potencial para promover o desenvolvimento, mas sobre os tipos apropriados de reformas. Em outras palavras, uma grande parte da discussão é sobre o modo como promover a reforma jurídica, e não sobre sua probabilidade de produzir bons resultados.

Em certa medida, o destaque dessas controvérsias reflete o sucesso da teoria otimista do direito e desenvolvimento como empreendimento intelectual. Tendo em vista a quantidade e a variedade de afirmações contraditórias sobre o significado de desenvolvimento e os tipos de reforma jurídica que levarão a ele, há mais do que o suficiente para alimentar o ceticismo em relação à capacidade de qualquer conjunto de reformas de alcançar seus objetivos. Assim, por exemplo, muitos dos autores reunidos no volume editado por Trubek e Santos têm dúvidas sobre a probabilidade de 
os projetos de reforma atuais alcançarem o objetivo da justiça social, a não ser indiretamente. ${ }^{95}$ No volume de Carothers, Kleinfeld critica os projetos de império do direito por tratarem as reformas jurídicas como fim, em vez de meio; Golub critica programas por não se concentrarem no objetivo de aliviar a pobreza e por superestimarem a importância da profissão jurídica e os atores estatais; ${ }^{96}$ e Mednicoff critica os programas americanos de império do direito no mundo árabe por enfocarem a reforma judicial em vez da educação cívica e profissional; 97 e muitos autores reclamam que os reformadores estrangeiros não reconhecem a importância do conhecimento local e da adaptação às condições locais na promoção das reformas jurídicas. ${ }^{98}$

Outras críticas da implementação dessas reformas tratam da competência dos atores estrangeiros que patrocinam muitas delas e o grau em que suas atividades são prejudicadas por conflitos de interesse e preconceitos intelectuais ou ideológicos. Por exemplo, Santos sugere que a competição por poder, recursos e prestígio dentro do Banco Mundial combina-se com uma falta de accountability para induzir unidades do banco a apoiar projetos de reforma jurídica sem refletir sobre o impacto delas sobre o desenvolvimento, seja antes ou depois do fato. ${ }^{99}$ De modo semelhante, profissionais da área jurídicas de países em desenvolvimento, inclusive juízes, consultores e ativistas, podem ter um interesse pessoal na promoção de reformas jurídicas sem levar em conta o impacto delas sobre a sociedade mais ampla. ${ }^{100}$ Santos sugere também que os preconceitos intelectuais e ideológicos que afetam funcionários tanto do Banco Mundial como dos governos que tomam empréstimos contribuem para as preocupações dessas instituições com certos tipos de reforma jurídica. ${ }^{101}$

Muitas dessas queixas também são feitas por colaboradores do volume organizado por Carothers. ${ }^{102}$ Além disso, Kleinfeld destaca que algumas reformas são instigadas por atores estrangeiros que tentam promover seus interesses próprios em questões como segurança mundial ou exportar determinados valores, em vez de ajudar os países pobres a se desenvolver. ${ }^{103}$ Channell observa também os problemas causados pela prática de agências de desenvolvimento de confiar em consultores externos que são supostamente expertos em seus campos, criando assim incentivos limitados para investir na aquisição de conhecimento específico de contexto, formular soluções novas e compartilhar informação. ${ }^{104}$ Piron mostra que muitas das dificuldades associadas à implementação de reformas jurídicas patrocinadas de fora têm por paralelo os problemas encontrados no fornecimento de outros tipos de ajuda ao desenvolvimento por atores externos. Ela sugere que os proponentes de reformas jurídicas deveriam basearse na expertise de outros praticantes e estudiosos da ajuda. ${ }^{105}$

Reconhecer os problemas potenciais de implementação de reformas jurídicas não implica necessariamente que os projetos de reformas nos países em desenvolvimento devam ser abandonados. Mas sugere que as expectativas em relação ao impacto dessas reformas deveriam ser modestas. A existência de desacordos teóricos em andamento implica que muitas reformas deveriam ser consideradas experimentos destinados a 
gerar conhecimento sobre a relação entre direito e desenvolvimento, em vez de aplicações das melhores práticas fundadas em princípios teóricos incontroversos. Enquanto isso, as reclamações constantes em relação às reformas patrocinadas por atores estrangeiros implicam algum grau de modéstia de parte dos atores externos (ou "de fora”) na promoção do império do direito ou de outras reformas jurídicas nos países em desenvolvimento e, em contrapartida, um papel maior para os "de dentro", com conhecimento detalhado tanto dos valores locais como dos inumeráveis fatores que determinam as consequências de adotar ou adaptar instituições jurídicas específicas.

Por fim, a combinação de ausência de consenso teórico sobre a direção apropriada da reforma e as dúvidas sobre reformas apoiadas por atores dos países desenvolvidos sugere que os pontos de referência para reformas jurídicas em muitos países em desenvolvimento não precisam ser instituições jurídicas que prevaleçam nos países desenvolvidos. Ao contrário, pode ser mais apropriado adaptar os arranjos jurídicos que prevalecem em outros países em desenvolvimento que compartilhem aspectos importantes dos valores, da história, da cultura e das tradições institucionais com as nações que se decidem por tais reformas.

\subsection{O PROBLEMA DO DETERMINISMO JURÍDICO}

O problema com o direito e desenvolvimento, tal como é praticado atualmente, pode ser mais do que uma mera questão de implementação ou sensibilidade política. A razão de as reformas jurídicas não cumprirem suas promessas talvez não seja simplesmente porque as pessoas não identificaram o pacote correto de reformas. Outra possibilidade é a de que os aspirantes a reformadores sejam necessariamente incapazes de efetuar mudanças jurídicas significativas. Talvez seja o caso de que os sistemas jurídicos só mudem em resposta a fatores históricos, econômicos, culturais ou políticos fundamentais e sejam, em larga medida, imunes a tentativas de reforma de cima para baixo.

Esse tipo de ceticismo sobre o papel independente que as instituições jurídicas desempenhariam na promoção da mudança social ocupa lugar importante nas obras em exame e tem uma longa e ilustre tradição intelectual.

\section{3. i Dependência de trajetória (PATh Dependency)}

Alguns teóricos parecem acreditar que as mudanças institucionais costumam ocorrer por acaso, e não de propósito. Por exemplo, Dam dedica uma boa quantidade de atenção cética às tentativas de explicar várias características importantes dos sistemas jurídicos contemporâneos fazendo referência a maior ou menor ligação, em sentido histórico, a uma das várias famílias jurídicas, a saber, o direito consuetudinário ou o direito civil alemão, francês ou escandinavo. ${ }^{106}$ O leitor desses estudos fica com a impressão de que o destino de muitas sociedades contemporâneas foi selado no século XIX, quando alguém decidiu que seriam governadas pelo direito civil francês ou o direito consuetudinário inglês. ${ }^{107}$ 
Douglass North esforçou-se muito para tentar explicar a relação entre eventos históricos e instituições contemporâneas. Ele se baseou nas teorias de dependência de trajetória, formuladas inicialmente no contexto da mudança tecnológica ${ }^{108}$ e sustentou que a mudança institucional é igualmente dependente. ${ }^{109}$ Afirmou, ainda, que a trajetória do desenvolvimento institucional, uma vez estabelecida, é reforçada por crescentes retornos que são característicos da estrutura institucional inicial: "Depois que a trajetória do desenvolvimento é determinada num certo sentido, as externalidades de rede, o processo de aprendizado das organizações e a moldagem subjetiva historicamente derivada das questões reforçam esse sentido". ${ }^{110}$ Portanto, é improvável que o desenvolvimento institucional seja interrompido até mesmo por uma transformação revolucionária na ordem política ou jurídica. ${ }^{111}$

Porém, embora seja convincente em determinado nível, em outro nível o conceito de North de dependência de trajetória é especificado de forma insuficiente para ser útil no mundo real. Sem maior elaboração, sua teoria não pode explicar os limites da dependência de trajetória, limites que existem, obviamente. Por exemplo, em 1974, somente 39 países - um em cada quatro do mundo - eram democráticos. Em 1997, 117 países - quase dois em três -, eram democráticos ${ }^{112}$ (reconhecendose que muitos desses regimes eram frágeis ou corruptos). ${ }^{113}$ No decorrer desse período, a maioria das antigas economias socialistas e comunistas também entrou em transição para a economia de mercado, com graus variados de sucesso. E alguns países em desenvolvimento, em especial no leste asiático, realizaram, com notável êxito, transformações econômicas (e frequentemente políticas e jurídicas) em poucas décadas. Essas mudanças foram acompanhadas ou efetuadas por uma proliferação de novas leis e instituições políticas, jurídicas e econômicas, muitas vezes a contrapelo de velhas tradições antitéticas. Obviamente, a dependência de trajetória não é absoluta nem permanente. O reconhecimento da importância dos eventos históricos na moldagem das instituições jurídicas do presente ainda deixa em aberto a questão da possibilidade de os reformadores alterarem deliberadamente o curso dos eventos atuais para provocar mudanças jurídicas que venham a beneficiar a sociedade. Assim, voltamos nossa atenção para teorias que identificam fatores econômicos, políticos e culturais mais específicos que limitam o alcance da reforma jurídica em qualquer contexto dado.

\subsubsection{TeORIAS ECONÔMICAS}

Parece intuitivamente plausível que o próprio fato da falta de desenvolvimento econômico possa impedir os países em desenvolvimento de empreender com sucesso reformas jurídicas sem apoio externo. Existem custos reais associados à operação de instituições jurídicas sofisticadas, sobretudo os custos de treinamento e de manutenção do pessoal habilitado para o funcionamento de tribunais e outras instituições jurídicas, para minutar legislação e disseminar informações sobre o conteúdo das 
leis. ${ }^{114}$ Está igualmente claro que alguns países em desenvolvimento não se mostram dispostos ou não têm condições para arcar com esses custos. Em seu artigo incluído na coletânea de Carothers, Piron descreve situações na Nigéria em que os juízes cujo acesso a relatórios jurídicos dependia de advogados que compareciam diante deles, ou em Ruanda, onde, em 1997, havia cerca de 50 juízes, 20 promotores e 50 advogados para uma população de 7,5 milhões. ${ }^{115}$ Ela conclui que são necessários “investimentos maciços" no setor de justiça na África. 116

Por outro lado, há motivos para fazer uma pausa antes de supor que a falta de desenvolvimento econômico representa per se um obstáculo insuperável para a criação de instituições jurídicas de alta qualidade. Em primeiro lugar, a proporção da riqueza de uma sociedade alocada para a manutenção de suas instituições jurídicas depende, em parte, da natureza dessas instituições. O aspecto mais óbvio é que a quantidade de recursos públicos disponíveis para financiar as instituições jurídicas depende muito da qualidade das instituições responsáveis pela coleta de impostos.

Um segundo motivo para que a riqueza não seja um pré-requisito da qualidade institucional é que instituições excelentes talvez não sejam muito dispendiosas. Como observamos acima, os principais custos associados ao funcionamento de instituições jurídicas são os de pessoal. Porém, eles tendem a ser determinados, sobretudo, pela oferta de mão-de-obra com as habilidades pertinentes, e não simplesmente pela riqueza nacional. Alguns países pobres, no sentido de ter baixos níveis de renda nacional e/ou dotação limitada de recursos naturais, possuem, não obstante, populações relativamente mal pagas, mas bem instruídas. Nesses países, os custos da manutenção de instituições jurídicas de alta qualidade podem não ser proibitivos. ${ }^{117}$ Ademais, em alguns casos, a qualidade das instituições manifesta-se em sua capacidade de limitar, em vez de expandir, o papel do Estado. Por exemplo, normas jurídicas que limitam a capacidade do governo de prender os oponentes políticos ou regulamentar a mídia são exemplos possíveis. Esses tipos de instituições de alta qualidade tenderão a conservar recursos físicos e humanos e, assim, serem menos caras que instituições de pior qualidade.

Uma terceira razão para questionar o pressuposto de que a qualidade institucional é fortemente determinada pela riqueza é o fato de ser possível que boas instituições jurídicas se paguem. Em outras palavras, talvez seja possível recuperar os benefícios de investir em instituições jurídicas tributando o aumento da atividade econômica estimulado pela melhoria das instituições. Nesse caso, enquanto o governo tiver acesso ao crédito, as restrições da riqueza não devem afetar sua capacidade nem seus incentivos para investir em instituições de alta qualidade.

\subsubsection{TeOrias políticas}

Um refrão comum ao longo do livro de Carothers é que os fatores políticos são determinantes cruciais do sucesso ou não das reformas jurídicas. ${ }^{118}$ Do mesmo modo, ao menos alguns autores do volume editado por Trubek e Santos assumem ser 
evidente que subjacentes às várias lutas sobre a direção da reforma jurídica se encontram ideologias e interesses políticos em conflito. ${ }^{119}$ (Dam reconhece o argumento, mas indica que as questões políticas estão fora do alcance de seu livro.) $)^{120}$ Infelizmente, nenhum dos livros faz um esforço sustentado de generalização das circunstâncias em que é provável que os fatores políticos sejam mais ou menos conducentes a determinados tipos de reformas. Há, no entanto, um grande corpo de literatura que trata dessa questão.

Muitos estudiosos sugerem que a qualidade das instituições jurídicas depende, em última análise, do interesse daqueles que exercem o poder político em criar instituições jurídicas que melhorem o bem-estar geral da sociedade ou, principalmente, em extrair renda em benefício próprio.

Alguns teóricos sustentam que a resposta a essa questão é determinada com frequência por tradições políticas moldadas na era colonial. Eles remontam o surgimento de Estados autoritários predadores a instituições coloniais criadas com objetivos similares. ${ }^{121} \mathrm{Em}$ uma recente extensão dessa linha de argumentação, Acemoglu, Johnson e Robinson sugerem que o fato de os europeus tentarem ou não montar um "Estado extrativo", em oposição a uma "neo-Europa" nas colônias foi influenciado significativamente por fatores geográficos que, por sua vez, determinaram a viabilidade da colonização europeia: "Em lugares onde o ambiente doentio não era favorável à colonização europeia, a sorte estava contra a criação de neo-Europas e era mais provável a formação de um Estado extrativo". ${ }^{122}$ Eles corroboram essa teoria usando uma análise regressiva de múltiplos países que mostra fortes relações positivas entre taxas de mortalidade de colonos europeus, qualidade das instituições coloniais e das instituições atuais, e renda per capita.

Outros estudiosos dão preeminência ao poder que os atores estrangeiros continuam a exercer sobre países em desenvolvimento. Por exemplo, para os teóricos da dependência, o foco está no poder que as metrópoles exercem sobre sociedades periféricas como principais fatores determinantes da forma das instituições jurídicas em sociedades dependentes. Em vez de explorar métodos de reformar essas instituições, os teóricos da dependência centram a atenção nos métodos de promover mudanças fundamentais no equilíbrio de poder econômico e político nas sociedades dependentes. Eles defendem a substituição de regimes dominados por atores estrangeiros ou por uma elite local relativamente pequena, ou por governos mais populistas que adotariam políticas econômicas socialistas. Nessas teorias, com frequência, presume-se simplesmente que a introdução do socialismo levaria inevitavelmente a uma série de reformas institucionais projetadas para provocar redistribuições significativas de riqueza e poder. ${ }^{123}$

Numa direção um pouco diferente, outros teóricos exploraram o modo como os fatores geográficos influenciam o surgimento de instituições políticas predatórias ou benévolas. ${ }^{124}$ Por exemplo, Engerman e Sokoloff afirmaram que sociedades com 
grande dotação de recursos naturais cuja exploração envolve economias de escala tendem a ter distribuições desiguais de renda, riqueza e poder político. ${ }^{125}$ Referindo à experiência do Novo Mundo, eles argumentaram que as elites das sociedades das Américas, caracterizadas por desigualdade extrema durante a era colonial, relutaram depois em adotar instituições que proporcionassem acesso amplo a oportunidades econômicas, inclusive instituições que provavelmente facilitariam a industrialização. ${ }^{126}$

Numa linha semelhante, Auty sustenta que nas sociedades bem dotadas de recursos naturais, que geram grandes rendas econômicas facilmente apropriáveis, é provável que o governo seja capturado por indivíduos ou grupos interessados na predação, em vez de no desenvolvimento; a implicação disso é que países ricos em recursos naturais tenderão a ter governos relativamente ruins (a assim chamada maldição dos recursos). ${ }^{127}$ Ao contrário, em sociedades pobres de recursos, é menos provável que o Estado seja capaz de sustentar transferências ineficientes e é mais provável que resista a pressões redistributivas. Nessas sociedades, é provável que surja um Estado desenvolvimentista caracterizado por um compromisso com a melhora da produtividade.

Outras teorias ainda concentram-se nos modos como divisões duradouras ao longo de linhas étnicas, religiosas, linguísticas ou econômicas impedem o surgimento de um governo realmente benévolo. A ideia básica é que em sociedades divididas cada grupo busca estimular o Estado a agir em apoio de seus interesses especiais, à custa de interesses mais amplos e abrangentes. Por exemplo, diz-se com frequência que a política de muitos países da África subsaariana é essencialmente uma batalha entre etnias pelo controle do Estado motivada pelo fato de que o controle do aparato estatal cria a oportunidade de transferir riqueza de um grupo para outro. ${ }^{128}$ Tendo em vista que um sistema jurídico de alta qualidade tem muitas características de um bem público, o compromisso difuso dos cidadãos com ideais como o império do direito pode não se traduzir numa mobilização política efetiva por reforma. ${ }^{129}$ Dentro dessa linha de raciocínio, O’Donnell argumenta que a desigualdade severa impede que os membros mais privilegiados da sociedade reconheçam os desprivilegiados como membros iguais da sociedade que têm direito a um tratamento respeitoso em suas interações com o sistema jurídico. ${ }^{130}$

Teorias mais dinâmicas sobre as relações das condições políticas com as mudanças jurídicas tratam menos do exercício do poder político de modo predatório ou benevolente e mais do grau de competição e de conflito pelo poder político. Os recursos perdidos por esse tipo de competição poderiam, presumivelmente, ser canalizados para a melhoria das instituições jurídicas. Ademais, o conflito político crônico provocado por profundas divisões sociais pode levar à instabilidade política. Por exemplo, Alesina e Perotti afirmam que a desigualdade extrema de renda alimenta o descontentamento social e, assim, exacerba a instabilidade política. ${ }^{131}$ De modo semelhante, Amy Chua sustenta que a instabilidade sociopolítica é provável quando as desigualdades econômicas seguem as divisões étnicas, de modo que a riqueza se concentra nas 
mãos de minorias étnicas. De acordo com Chua, em muitos casos, esse fenômeno tende a persistir ou mesmo exacerbar-se com a atividade das forças do livre mercado e tende a fomentar a inveja e o ódio entre etnias. Em consequência, certos tipos de sociedades, especificamente, aquelas que tentam ao mesmo tempo adotar o livre mercado e a democracia, são inerentemente instáveis. ${ }^{132}$ Por sua vez, a instabilidade política pode levar à instabilidade jurídica que, como já observamos, é amplamente considerada incompatível com o império do direito. ${ }^{133}$

\section{$2 \cdot 3 \cdot 4$ TEORIAS CULTURAis}

Os três livros em exame contêm reconhecimentos do papel desempenhado por fatores sociais ou culturais na moldagem de instituições jurídicas e da trajetória geral do desenvolvimento. ${ }^{134}$ Porém, somente a obra de Dam oferece uma discussão aprofundada da afirmação cética de que a cultura tem uma importância primordial. ${ }^{135}$

Esse tipo de ceticismo tem, na verdade, uma tradição ilustre. Ao longo dos séculos, vários teóricos sugeriram que os fatores sociais e culturais desempenham o papel mais significativo na determinação de graus relativos de desenvolvimento. ${ }^{136}$ Um dos argumentos mais influentes nesse sentido foi a sugestão de Max Weber de que os valores associados ao protestantismo europeu ocidental são particularmente conducentes ao capitalismo. ${ }^{137}$ David Landes, em sua contribuição para Culture Matters, afirma: "Max Weber tinha razão. Se aprendemos alguma coisa com a história do desenvolvimento econômico é que a cultura faz toda a diferença". ${ }^{138}$ Mais recentemente, baseando-se numa tipologia criada por Mariano Grondona, em artigo incluído em Culture Matters, Harrison preparou uma complexa tipologia de culturas propensas e culturas resistentes ao progresso, descrevendo como elas variam em termos de fatores como atitudes em relação à capacidade de controlar o próprio destino, pontualidade, poupança, educação, risco e identificação com pessoas fora da família. ${ }^{139}$

Os indícios de que instituições de alta qualidade estão conectadas causalmente ao desenvolvimento não prejudicam as teorias de orientação cultural. Os deterministas culturais podem argumentar que, embora as medidas de qualidade institucional possam ser fatores determinantes próximos de graus de desenvolvimento, a própria qualidade institucional é, por sua vez, determinada principalmente por fatores culturais. Nessa linha de argumentação, alguns estudos concluem que países predominantemente protestantes costumam ter governos melhores que países predominantemente católicos ou muçulmanos, sugerindo a hipótese de que Estado e igreja estão mais separados em países protestantes, realçando freios e contrapesos, e que o protestantismo é mais individualista e menos hierárquico e familista que outras religiões, aumentando a probabilidade de desacordo com políticas ou práticas governamentais indesejáveis. ${ }^{140}$

Robert Putnam oferece outro ponto de vista. Em seu famoso estudo sobre as tradições cívicas na Itália, em que contrasta o norte e o sul do país, ele sustenta que certas atitudes e práticas sociais profundamente enraizadas podem reforçar ou enfraquecer a 
legalidade. De acordo com Putnam, uma comunidade cívica "marcada por uma cidadania ativa e de espírito público, por relações políticas igualitárias, por um tecido social de confiança e cooperação"141 tem mais capacidade de superar dilemas de ação coletiva e perseguir o que Alexis de Tocqueville chamou de "interesse próprio entendido corretamente" - a saber, objetivos que servem aos interesses mais amplos da sociedade. ${ }^{142}$ Putnam argumenta que uma comunidade cívica tem estoques maiores de "capital social”, o qual consiste naqueles aspectos do engajamento cívico, inclusive normas de reciprocidade e redes horizontais de engajamento ć́vico, que facilitam a cooperação entre os membros de uma comunidade. ${ }^{143} \mathrm{~A}$ reciprocidade estimula a confiança social e desestimula o comportamento oportunista, uma vez que a deserção de uma transação no presente acarreta punição no futuro. ${ }^{144}$ Putnam prossegue afirmando que as normas de reciprocidade e redes de engajamento cívico realçam a legalidade ao criar uma demanda por instituições de qualidade melhor e facilitar a ação coletiva exigida para criá-las. ${ }^{145}$ Essas normas melhoram também o desempenho das instituições ao criar uma expectativa de que os outros obedecerão as regras. Ele rejeita os argumentos (com frequência associados à teoria da Escolha Pública) de que as redes em que tais normas prevalecem deveriam ser consideradas "coalizões distribucionais" que tentam redistribuir riqueza para elas mesmas em vez de buscar melhorar a condição da sociedade como um todo. ${ }^{146}$

Alguns dos trabalhos mais recentes nessa linha foram enriquecidos com insights derivados da psicologia transcultural. Os psicólogos dessa escola compilaram uma quantidade impressionante de indícios que sugerem que há variações importantes de "valores culturais" entre os países. ${ }^{147}$ Uma das forças dessa literatura é o fato de que ela caracteriza as culturas com referência a análises de respostas a questões de pesquisas padronizadas internacionalmente, tornando assim possível que as culturas sejam descritas em termos objetivos, em vez de subjetivos. Com base nessa literatura, Amir Licht e seus coautores afirmaram que as variações entre países de valores culturais estão correlacionadas com variações em respeito ao império do direito, corrupção e accountability democrática. ${ }^{148}$ Por exemplo, eles afirmam que a ênfase nos valores culturais de autonomia ou individualismo, em oposição a integração e coletivismo, é compatível com o império do direito - que eles definem simplesmente como o grau em que as regras são respeitadas e impostas -, com a ausência de corrupção e a accountability democrática. Parte da lógica por trás desse argumento parece ser que o império do direito e a ausência de corrupção tendem a propiciar aos indivíduos certeza quanto a seus direitos e, assim, possibilitar que persigam seus objetivos. Ao contrário, uma sociedade que valoriza a integração ou o coletivismo irá, provavelmente, estimular as pessoas a buscarem orientação em fontes não jurídicas, como a tradição e a família.

Outro conjunto de teorias de orientação cultural concentra-se, no entanto, no papel desempenhado por um aspecto definido de modo mais estrito da cultura de 
uma sociedade, especificamente a cultura predominante entre os profissionais do direito dessa sociedade. Esse corpo de literatura também remonta ao século XIX. Por exemplo, teóricos como Maine e Savigny atribuíam o brilho do direito romano ao fato de que, por alguma razão, a cultura romana glorificava os juristas que, por um longo período de tempo, se dedicaram ao objetivo de melhorar continuamente as instituições jurídicas de Roma. ${ }^{149}$

Mais recentemente, Alan Watson ofereceu numerosos exemplos em apoio de sua afirmação de que as leis não se adaptam necessariamente para refletir condições sociais, políticas ou econômicas dominantes. Ele cita normas jurídicas que não beneficiam ninguém dentro da sociedade, mas que, não obstante, persistiram por séculos, sobrevivendo a revoluções sociais, políticas e econômicas. ${ }^{150}$ Watson sugere que antes de ser determinada por fatores políticos ou econômicos, a mudança jurídica é impulsionada principalmente por juristas que, devido às características peculiares da sua profissão, ou tomam emprestado normas jurídicas de outras nações, ou as desenvolvem por analogia a normas existentes dentro de seu próprio sistema. Essa predisposição ao transplante, alega Watson, com frequência deixa cegos os juristas para a qualidade ruim de uma determinada norma, ou para sua inadequação para a sociedade que a toma emprestado. ${ }^{151}$

Um contraste notável é oferecido por Paul Mahoney, que sugeriu que os traços culturais tipicamente associados ao direito consuetudinário inglês e ao direito civil francês são distintos e que as distinções são economicamente significativas. Com base em trabalho anterior de Hayek, Mahoney sustenta que a ideologia subjacente ao direito inglês promove a liberdade individual e a liberdade da intervenção do governo. ${ }^{152}$ Ao contrário, a ideologia subjacente ao direito civil francês, que está encarnada em um código patrocinado pelo Estado, promove os direitos coletivos e contempla um maior ativismo do governo. De acordo com esse autor, devido à resistência ideológica do direito consuetudinário à interferência governamental, o grau de separação formal entre o judiciário e os outros ramos do governo costuma ser maior nos países que seguem o modelo inglês. $\mathrm{O}$ isolamento maior da influência política aumenta a previsibilidade e, portanto, a estabilidade do direito consuetudinário. Ao contrário, a tradição mais intervencionista do direito civil francês oferece um campo maior para a alteração dos direitos de propriedade e contrato. Isso, por sua vez, pode reduzir a confiança dos cidadãos na ordem jurídica formal. ${ }^{153}$ Mahoney apoia esse argumento com dados empíricos mediante análise regressiva que mostra que os países com tradição de direito consuetudinário tiveram, em média, ao longo do tempo, um crescimento econômico significativamente maior que aqueles com tradição do direito civil. ${ }^{154} \mathrm{Em}$ linha semelhante, Thomas Heller afirma que demasiados esforços recentes de reforma do império do direito nos países em desenvolvimento se centraram nos tribunais e trataram, de forma demasiado estrita, de aumentar o rendimento dos tribunais existentes (fazendo mais do mesmo) e deram pouca atenção a aspectos da cultura jurídica 
244 : A RELAÇÃO ENTRE DIREITO E DESENVOLVIMENTO: OTIMISTAS VERSUS CÉTICOS

e política que constrangem seus mandatos e funções. Ele sustenta que a promoção de alternativas competitivas ao sistema formal de tribunais poderia ser mais eficaz no desbaratamento da cultura jurídica tradicional. ${ }^{155}$

Evidentemente, para se qualificarem como teorias céticas para nossos propósitos, as teorias culturais da evolução jurídica devem alegar não somente que a cultura influencia as instituições jurídicas, mas também que a cultura não é ela mesma influenciada por mudanças nessas instituições. Com efeito, as perguntas sobre o que impulsiona a mudança cultural, o grau em que a cultura é dependente de trajetória, se a mudança cultural pode ser intencionalmente provocada por mudanças institucionais e políticas e se e em que circunstâncias as mudanças culturais são socialmente desejáveis são questões de intensa controvérsia. ${ }^{156}$

Gillian Hadfield, por exemplo, afirmou recentemente que variações significativas na cultura jurídica, inclusive aquelas comumente atribuídas à herança do direito consuetudinário versus direito civil, poderiam ser explicadas por fatores institucionais tais como estratégias para selecionar e recompensar juízes ou procedimentos de julgamento. ${ }^{157}$ Há certamente espaço para mais pesquisas sobre esses tópicos. Mas por enquanto, o problema do conhecimento permanece.

\subsection{A Alternativa informal}

A abordagem mais cética da questão da valia das reformas jurídicas afirma que praticamente não há conexão entre a natureza do sistema jurídico de uma sociedade e suas perspectivas de desenvolvimento. Em outras palavras, o direito não importa, nem mesmo como veículo por meio do qual fatores econômicos, culturais ou políticos não jurídicos exercem sua influência. Curiosamente, esse ponto de vista radicalmente cético recebe pouca atenção nos livros em exame.

Essa forma de ceticismo está fundada na crença de que o sistema jurídico - que já definimos como um sistema que envolve administração de normas por atores estatais - é apenas um dos vários meios potencialmente viáveis de controle social. Essa ideia - foi prefigurada pela declaração de Trubek e Galanter - de que "o modelo [jurídico liberal] presume que as instituições estatais são o lugar principal do controle social, ao passo que em boa parte do Terceiro Mundo, o domínio da tribo, do clã e da comunidade local é muito mais forte do que o do Estado-nação". Em outras palavras, as normas e instituições informais associadas à tribo, ao clã e à comunidade podem minar ou tomar o lugar das normas e instituições jurídicas. ${ }^{158}$ Isso abre a possibilidade de que, em um amplo espectro de contextos, as normas sustentadas por códigos morais internalizados ou pelo medo de sanções impostas por atores não jurídicos normas informais - possam provocar os tipos de comportamento essenciais para o funcionamento de uma sociedade desenvolvida, tais como a manutenção de promessas, o respeito por normas compartilhadas que governam o uso da propriedade e a solução não violenta de disputas. 
Esse ponto de vista, embora um pouco diferente, está relacionado a algumas das teorias deterministas analisadas na seção anterior deste artigo. $\mathrm{O}$ argumento dos deterministas é que os fatores econômicos, culturais e políticos exercem influências irresistíveis sobre o comportamento das pessoas que criam as normas jurídicas, as quais, por sua vez, influenciam o comportamento de outros membros da sociedade. Ao contrário, o argumento dos informalistas é que os fatores econômicos, culturais e políticos - talvez os mesmos identificados pelos deterministas - influenciam diretamente o comportamento de uma ampla gama de membros da sociedade, independentemente da influência que possam ter sobre o comportamento dos legisladores ou da forma das normas jurídicas. A diferença entre esses dois pontos de vista teóricos tem uma grande importância prática, porque segundo os deterministas, a existência de um sistema jurídico de alta qualidade é um pré-requisito importante para o desenvolvimento e pode, no mínimo, servir como marco de referência útil para os profissionais do desenvolvimento. Ao contrário, para os informalistas, o desenvolvimento não está necessariamente associado a algum tipo determinado de sistema jurídico. Sob esse ponto de vista, um sistema jurídico de alta qualidade não é um pré-requisito para o desenvolvimento e não seria sensato usar a qualidade desse sistema como ponto de referência para o desenvolvimento.

Os defensores mais vigorosos da posição informalista tendem a estar entre as fileiras dos estudiosos que tratam do papel do direito no desenvolvimento econômico das sociedades do Leste Asiático. ${ }^{159}$ Em um importante artigo sintético, Jayasuriya afirma que a economia de mercado ocidental se caracteriza por transações entre agentes econômicos independentes facilitadas pelo sistema jurídico. ${ }^{160}$ No entanto, o capitalismo no leste da Ásia caracteriza-se por redes de relações, tanto entre agentes econômicos como entre esses agentes e o Estado, que operam, em larga medida, fora do sistema jurídico formal. Nesse tipo de capitalismo, o sistema jurídico desempenha um papel marginal e, assim, investimentos substanciais em reforma jurídica têm um valor duvidoso. ${ }^{161}$

Dentro desse raciocínio, as interpretações mais radicais das impressionantes taxas de crescimento da China, apesar das classificações ruins segundo a maioria dos critérios convencionais de qualidade das leis e das instituições jurídicas (o assim chamado "enigma chinês"), sugerem que as leis e as instituições formais não são fatores determinantes essenciais do desenvolvimento econômico de um país. Mecanismos informais que reconheçam e protejam os direitos da propriedade privada e assegurem o cumprimento de contratos são, com frequência, substitutos eficazes (embora alguns analistas sustentem que a China talvez tenha chegado, agora, a um estágio de desenvolvimento econômico em que atingiu as limitações inerentes a esses mecanismos). ${ }^{162}$

A ideia de que as normas informais poderiam regular com sucesso muitas interações privadas entre indivíduos, em sociedades tanto em desenvolvimento como desenvolvidas, é aceita por um forte contingente de teóricos ocidentais do direito, 
entre eles, figuras proeminentes como Stewart Macaulay, Robert Ellickson e Lisa Bernstein. ${ }^{163}$ Quanto aos teóricos de outras áreas, até mesmo aqueles cujo trabalho é, às vezes, associado ao otimismo jurídico, uma leitura mais atenta de suas obras mostra que são ambivalentes quanto à importância relativa de normas legais e não legais. Por exemplo, Douglass North, que costuma ser reconhecido como um dos pioneiros da Nova Economia Institucional, define instituições como:

[...] as regras do jogo de uma sociedade [...] Elas são compostas de regras formais (direito estatutário, direito consuetudinário, regulamentações), restrições informais (convenções, normas de comportamento e códigos de conduta voluntários) e as características de imposição de “ambos” [grifo do autor]. ${ }^{164}$

Graças às obras desses e de outros estudiosos, reconhece-se agora que fatores não jurídicos determinam a relevância e o impacto do direito privado, ou seja, o corpo de normas jurídicas, tais como leis de contrato, propriedade, responsabilidade civil e empresarial que regulamentam as interações entre indivíduos. ${ }^{165}$

As normas informais parecem desempenhar um papel igualmente importante na determinação da relevância e do impacto das normas do direito público - isto é, normas jurídicas formais que governam o comportamento dos funcionários públicos -, que tendem a preocupar os novos constitucionalistas. Suponhamos, por exemplo, que aceitamos o conceito de que democracia, separação de poderes e liberdade de imprensa contribuem para o desenvolvimento. Ainda restam motivos convincentes para crer que o grau de compromisso de uma sociedade com a democracia e a separação de poderes tem relativamente pouca relação com as normas jurídicas governantes e mais com a natureza e o conteúdo de várias normas não jurídicas - inclusive aquelas discutidas por Putnam e Licht et al. - que, de um lado, definem o comportamento apropriado para os funcionários públicos e, de outro, definem graus apropriados de engajamento cívico para os cidadãos comuns. ${ }^{166}$ A força dessas normas informais dependerá, em parte, do grau em que foram internalizadas e da capacidade das facções oponentes de impor sanções não jurídicas aos atores políticos que as violam. A potência das sanções não jurídicas dependerá, por sua vez, da distribuição do poder político na sociedade pertinente e isso, como já discutimos, dependerá de fatores como a relativa riqueza das facções oponentes, da presença de recursos naturais que possam ser apropriados por aqueles que controlam o Estado, da presença de divisões étnicas profundamente arraigadas, etc. ${ }^{167}$

Do mesmo modo, a liberdade de imprensa é somente em parte um produto de normas jurídicas formais como as leis de difamação e calúnia e aquelas que governam o acesso à informação. ${ }^{168}$ Ela depende também de normas sustentadas por fatores não jurídicos, tais como tradição de jornalismo investigativo e a estrutura dos dois lados de oferta e demanda dos mercados de serviços de comunicação. ${ }^{169}$ Como observou Rose-Ackerman, em alguns países menos desenvolvidos, uma parcela significativa da 
população adulta é analfabeta e, portanto, pode não ser capaz de (ou não estar inclinada a) usar os meios de comunicação (ao menos os impressos) como meio de controlar a accountability do governo. ${ }^{170}$

Tendo em vista seus fortes fundamentos teóricos, surpreende o fato de que esse conceito altamente cético das reformas jurídicas receba relativamente pouca atenção dos livros em exame. Diga-se a seu favor que Carothers levanta explicitamente a questão da necessidade do império do direito para o desenvolvimento econômico e a democracia. ${ }^{171}$ No fim das contas, no entanto, não está claro até que ponto suas opiniões atuais divergem da posição que defendeu em seu ensaio anterior reproduzido na coletânea, no qual declara: "Embora sua capacidade de operar maravilhas tenha sido exagerada, a conveniência do império do direito está clara". ${ }^{172} \mathrm{Na}$ verdade, somente um colaborador do volume de Carothers aceita seu convite para questionar se o direito tem realmente importância. Em seu capítulo, Upham, um especialista no papel do direito na China e no Japão, surpreende ao assinalar vigorosamente que o desenvolvimento econômico mais impressionante do Japão coincidiu com o período em que o governo japonês limitou deliberadamente o papel que o sistema jurídico desempenhava na sociedade japonesa, tendo, entre outras coisas, limitado drasticamente o número de advogados qualificados. ${ }^{173}$

Uma postura similar é evidente na coletânea de Trubek e Santos. O último cita uma grande quantidade de indícios que sugerem que um judiciário eficiente e direitos de propriedade claramente definidos têm, com frequência, relevância limitada para os empreendedores nos países em desenvolvimento. ${ }^{174}$ Porém, os outros colaboradores do volume gastam pouco tempo para examinar criticamente o pressuposto de que o direito desempenha um papel causal significativo na promoção do desenvolvimento. Por exemplo, embora Rittich admita a ideia de que "normas informais podem suplementar ou mesmo substituir leis formais", ${ }^{175}$ no fim, sua visão é que a realização da justiça social implica necessariamente uma reforma jurídica e que o melhor curso de ação para os reformadores preocupados com a justiça social envolve "levar o direito ainda mais seriamente". 176

A posição mais interessante sobre essa questão talvez seja a de Dam. Ele reconhece o valor da questão sobre a importância ou não do direito e a ausência de uma prova conclusiva de que realmente importa. Porém, em um trecho que vale a pena citar por inteiro, declara:

O leitor talvez pergunte se não deveríamos esperar por uma prova melhor de que o direito em si mesmo importa antes de tratar das implicações práticas. Minha formação de acadêmico tende a me fazer simpatizar com essa abordagem. Mas minha experiência de formulador de políticas me faz rejeitá-la enfaticamente. As decisões políticas sobre desenvolvimento econômico são tomadas todos os dias em cada país em desenvolvimento e também em agências 
bilaterais e multilaterais do mundo desenvolvido. A política econômica é necessariamente levada a cabo sob condições de incerteza - incerteza sobre os fatos e sobre os princípios e causas subjacentes. Desse modo, as decisões sobre mudar ou não as instituições jurídicas e as leis substantivas serão tomadas - nem que seja por inação - em campos substantivos, tais como terras, mercados de ações e mercados de créditos, bem como na imposição, incluindo o papel e a natureza do judiciário. Uma vez que os formuladores de políticas sabem que as instituições importam para o desenvolvimento econômico, seria insensatez deles supor que as instituições jurídicas - as regras do jogo e as organizações do direito, em especial o judiciário - não têm importância. ${ }^{177}$

O que Dam parece estar dizendo aqui é que seu livro destina-se a ajudar a responder a questão relativa a que tipos de reforma jurídicas promoverão o desenvolvimento econômico depois de tomada a decisão de empreender a reforma. Ele não parece inclinado a tratar da questão prévia da necessidade de fazer as reformas jurídicas, dizendo que "a prova da correção da premissa de que o direito importa seria um exercício totalmente diferente, mais apropriado aos economistas e talvez outros cientistas sociais que para juristas e formuladores de políticas”. ${ }^{178}$ Porém, ele talvez reconheça que, enquanto houver uma genuína incerteza quanto à importância do direito, há uma clara possibilidade de que a reforma jurídica não teria nenhum impacto positivo sobre o desenvolvimento, nem os recursos investidos nela poderiam ser investidos de outro modo que causasse um impacto maior.

Dada a importância dessa questão, pensamos que é lamentável que Dam e a maioria dos outros estudiosos representados em livros recentes sobre direito e desenvolvimento a deixem de lado. Ao contrário de Dam, acreditamos que os teóricos do direito podem, talvez em colaboração com cientistas sociais, contribuir para a pesquisa sobre essas questões e os estimularíamos a fazê-lo.

\section{OS DADOS EMPÍRICOS APOIAM OS OTIMISTAS?}

O tratamento das questões em torno da importância do direito, das circunstâncias econômicas, culturais e políticas sob as quais uma reforma jurídica significativa é possível, dos tipos de reformas que devem ser empreendidas e dos melhores meios de implementá-las, tudo isso exige pesquisas empíricas, além de formulações teóricas. A literatura empírica existente sobre estas questões oferece fundamentos modestos para a posição otimista, mas permanece altamente inconclusiva.

\section{I DAdos QUe FaVoreceM os OTIMISTAS}

Em anos recentes, as principais análises empíricas da relação entre instituições e desenvolvimento (e império do direito e desenvolvimento) foram um conjunto de 
análises estatísticas transnacionais projetadas para investigar o grau em que várias medidas de qualidade institucional explicam medidas de desenvolvimento, tais como, níveis de renda per capita, taxas de mortalidade infantil e taxas de alfabetização. Esses estudos são agora numerosos demais para serem examinados individualmente mas, em termos gerais, os resultados dão sustentação à perspectiva otimista.

O teor geral dessa perspectiva pode ser captado no exame de um trabalho particularmente influente intitulado "Governance Matters". Esse estudo foi realizado por Kaufmann, Kraay e Zoido-Lobaton, todos ligados ao Banco Mundial, como parte da pesquisa em andamento dessa instituição sobre governança, que tem sido atualizada periodicamente. ${ }^{179} \mathrm{O}$ projeto "Governança" do Banco Mundial compreende a compilação de um grande número de medidas subjetivas de qualidade institucional (para quase duzentos países) - dados significativos obtidos de grupos de especialistas nos países ou surveys de residentes - e seu agrupamento em seis grupos: "voz e accountability", "estabilidade política”, "eficácia do governo", "qualidade regulatória”, "império do direito" e "controle da corrupção".

Os autores de "Governance Matters" criaram índices que medem a qualidade institucional dentro de cada uma dessas seis dimensões, bem como um índice de "governança" composto projetado para medir a qualidade total da governança em uma sociedade. Eles então fizeram a regressão de três medidas de desenvolvimento - PIB per capita, mortalidade infantil e alfabetização adulta - sobre esses índices. Encontraram correlações fortes (referem-se à causalidade) entre cada um de seus subíndices de qualidade institucional, inclusive do índice de império do direito, bem como de um índice composto de governança e suas medidas de desenvolvimento. Daí a conclusão de que a "Governança Importa". Em uma iteração mais recente desse trabalho, Kaufmann relata:

Conclui-se que os efeitos de uma governança melhor sobre a renda no longo prazo são muito grandes, com uma melhoria estimada de $400 \%$ na renda per capita associada a uma melhoria em governança de um desvio padrão, e melhoramentos similares na redução da mortalidade infantil e do analfabetismo. Para ilustrar, uma melhoria de um desvio padrão no império do direito em relação aos atuais níveis na Ucrânia para aqueles níveis médios predominantes na África do Sul levaria a uma quadruplicação na renda per capita no longo prazo. Um aumento maior na qualidade do império do direito (por dois desvios padrão) na Ucrânia (ou em outros países da antiga União Soviética) para o nível muito mais alto da Eslovênia ou da Espanha multiplicaria ainda mais esse aumento de renda per capita. Resultados semelhantes surgem de outras dimensões de governança: uma mera melhoria de um desvio padrão em voz e accountability do nível baixo da Venezuela para o da Coreia do Sul, ou em controle de corrupção do nível baixo da Indonésia para o nível médio do México, ou do nível do México para aquele da Costa 
Rica, estaria também associado a um aumento estimado de quatro vezes nas rendas per capita, bem como melhorias similares na redução da mortalidade infantil em 75\% e grandes ganhos na alfabetização. ${ }^{180}$

Baseados nos dados de Kaufmann et al., Rodrik, Subramanian e Trebbi, em trabalho recente intitulado "Institutions Rule: The Primacy of Institutions over Geography and Integration in Economic Development", 181 estimam as contribuições respectivas de instituições, geografia e comércio internacional na determinação dos níveis de renda em todo o mundo. Os autores concluíram que a qualidade das instituições tem mais importância do que o resto. Uma vez controladas as instituições, as medidas convencionais de geografia têm, na melhor das hipóteses, efeitos diretos sobre a renda, embora tenham um forte efeito indireto ao influenciar a qualidade das instituições. Do mesmo modo, uma vez controladas as instituições, o comércio é quase sempre insignificante, exceto por efeitos indiretos sobre as instituições.

Nesse estudo, os autores usam vários elementos que captam a proteção oferecida ao direito de propriedade e a força do império do direito. Para transmitir um sabor da natureza surpreendente de suas conclusões, Rodrik, Subramanian e Trebbi concluem que um aumento de um desvio padrão em qualidade institucional, correspondendo mais ou menos à diferença entre qualidade institucional medida na Bolívia e na Coreia do Sul, produz um aumento de dois pontos $\log$ em renda per capita, ou uma diferença de 6,4 vezes mais - a qual, não por coincidência, é também mais ou menos a diferença de renda entre os dois países.

Recentemente, ${ }^{182}$ Fukuyama, em uma breve resenha de parte da literatura empírica sobre fatores determinantes do desenvolvimento econômico, concluiu: "Creio que os institucionalistas ganharam essa discussão facilmente”.

Nós também acreditamos que a literatura empírica é coerente com a visão otimista de que as instituições são suscetíveis aos esforços deliberados de reforma e não são moldadas exclusivamente por forças econômicas, culturais ou políticas.

Para começar, o exame dos dados transnacionais revela que o desempenho das instituições jurídicas mostra uma variação considerável dentro dos países por períodos de tempo bem curtos. Isso é inconsistente com qualquer sugestão de que a qualidade dessas instituições é moldada de forma importante por características econômicas, culturais ou políticas das sociedades, as quais, em larga medida, são imutáveis. ${ }^{183}$ Porém, é verdade que essa prova não vai ao âmago da alegação dos céticos, ou seja, que as instituições jurídicas estão fora da manipulação deliberada. O fato de sua qualidade variar ao longo do tempo não descarta a possibilidade de que sejam moldadas por forças impessoais incontroláveis cujos efeitos variam ao longo do tempo.

Os dados transnacionais, entretanto, não revelam quaisquer traços culturais exógenos que expliquem essa proporção significativa de variação internacional em desempenho institucional, de modo a sugerir que é inútil considerar a manipulação 
deliberada das instituições jurídicas. Por exemplo, nos últimos anos, as teorias culturais da qualidade institucional mais aceitas basearam-se em alegações sobre as fraquezas da cultura jurídica francesa ou nas virtudes da cultura jurídica inglesa. Mas mesmo que sejam válidas, essas teorias pouco explicam as grandes variações que podemos observar entre países com heranças jurídicas semelhantes. ${ }^{184}$

Por exemplo, tanto Gana como Hong Kong experimentaram o domínio britânico e adotaram o direito consuetudinário, mas há diferenças marcantes no desempenho de suas instituições. De modo semelhante, Costa Rica e México herdaram instituições jurídicas derivadas indiretamente da França, mas as costa-riquenhas tiveram um desempenho significativamente melhor do que as mexicanas, para não mencionar outras jurisdições influenciadas pela cultura jurídica francesa.

Cremos que os dados transnacionais são também inconsistentes com a alegação específica de que a qualidade das instituições jurídicas é determinada totalmente pela interação de fatores geográficos e políticos. Por exemplo, numa série de importantes contribuições recentes, Acemoglu, Johnson e Robinson (AJR) interpretam indícios da existência de uma correlação negativa entre as taxas de mortalidade de colonos no século XIX e o desempenho recente de instituições jurídicas como prova de que esse desempenho é determinado pela interação de fatores econômicos e políticos que, por sua vez, determinam os tipos de instituições que os europeus estavam dispostos e eram capazes de estabelecer em suas colônias. ${ }^{185}$

Em nossa opinião, no entanto, esses dados não eliminam a possibilidade de influenciar a qualidade das instituições jurídicas mediante uma intervenção deliberada. Em primeiro lugar, os fatores econômicos e políticos que AJR identificaram não explicam todas as variações transnacionais em desempenho institucional. Seria de esperar que o impacto de políticas coloniais geograficamente determinadas diminuísse com a quantidade de tempo que se passou desde a independência e, ao atingirmos as duas últimas décadas do século XX, a maioria dos países colonizados já havia obtido sua independência. Em acordo com essa hipótese, Rodrik e seus coautores mostraram que o coeficiente sobre taxas de mortalidade de colonos em regressões sobre desempenho institucional declinaram de 0,94 na década de 1970 para 0,87 na de 1980 e 0,71 na de $1990 .{ }^{186}$

Mas o que é mais fundamental, não acreditamos que as correlações entre taxas de mortalidades dos colonos no passado e medidas de desempenho institucional, tanto históricas como contemporâneas, demonstrem causalidade. AJR sustentam que as altas taxas de mortalidade dos colonos levaram as potências europeias a fazer duas escolhas políticas fundamentais: evitar a colonização e estabelecer instituições exploradoras coerentes com "um Estado extrativista", em vez de uma "Neo-Europa". Mesmo que aceitemos a caracterização que eles fazem do dilema europeu, argumentaríamos que a combinação de condições geográficas inóspitas e poder político obrigava à primeira decisão política, mas não à segunda. A não ser que assumamos o 
ponto de vista de que racismo, cobiça e rapacidade são traços fundamentais e imutáveis da natureza humana, é difícil defender a posição de que a exploração das colônias sem colonizadores era inevitável. Essa política deve ser vista como uma decisão deliberada de parte dos europeus que foi possibilitada, mas não totalmente determinada, por condições geográficas e pela distribuição do poder.

Em suma, embora não conclusivos, os dados transnacionais não oferecem muito suporte para os céticos que se baseiam em versões bem conhecidas de determinismo econômico, cultural ou político. ${ }^{187}$ As variações em desempenho institucional ao longo do tempo são inconsistentes com as afirmações de que as instituições jurídicas são moldadas por fatores econômicos, culturais ou políticos imutáveis. Os dados também não sustentam as alegações de que a herança colonial, por meio de sua influência sobre a cultura jurídica ou outras escolhas políticas feitas pelos colonialistas europeus, explica tanto a variação entre países que merece ser considerada uma influência irresistível sobre a evolução das instituições jurídicas.

\subsection{OBSERVAÇÕes CÉTICAS}

Não obstante, há várias razões para que as análises estatísticas transnacionais discutidas na seção anterior devam ser interpretadas com alguma cautela. ${ }^{188}$ Chamamos a atenção para duas em particular. Em primeiro lugar, mesmo aceitando os resultados sem questioná-los, esses estudos não avançam muito no sentido de superar o problema do conhecimento. A natureza grosseira dos dados utilizados nesses estudos estatísticos transnacionais oferece muito pouca informação sobre quais traços de projetos de determinadas classes de instituições jurídicas, causalmente relacionadas com determinados resultados de desenvolvimento, são de particular importância.

Fukuyama - no artigo supracitado e no qual conclui que os institucionalistas ganharam facilmente a discussão, com os não constitucionalistas, sobre os fatores determinantes do desenvolvimento -, observa também que a administração pública não é uma ciência suscetível de formalização conforme um conjunto de regras e princípios universais, ${ }^{189}$ e que as instituições macropolíticas também não são suscetíveis de caracterização em termos de arranjos políticos formais ótimos. Ao contrário, a especificação plena de um bom conjunto de instituições será muito dependente do contexto, mudará com o tempo e interagirá com as normas, valores e tradições informais da sociedade em que estão enraizadas.

Do mesmo modo, Rodrik, Subramanian e Trebbi, no trabalho citado, apesar do título talvez triunfalista, chegam, na verdade, a conclusões bastante salutares e até acauteladoras: ${ }^{190}$

Quantas orientações nossos resultados oferecem aos formuladores de políticas que queiram melhorar o desempenho de suas economias? Não muitas. Claro, é útil saber que geografia não é destino, ou que se concentrar em aumentar as 
ligações da economia com os mercados mundiais provavelmente não produzirá convergência. Mas a orientação operacional que nosso resultado principal sobre a primazia da qualidade institucional oferece é extremamente pouca. [...] Ilustramos a dificuldade de extrair de nossos resultados informações relevantes para a formulação de políticas usando o exemplo dos direitos de propriedade. Obviamente, a presença clara desses direitos é um elemento-chave, senão o mais fundamental, no ambiente institucional que molda o desempenho econômico. Nossos resultados indicam que quando os investidores acreditam que seus direitos de propriedade estão protegidos, a economia acaba mais rica. Mas nada está implícito sobre a forma real que esses direitos deveriam assumir. Não podemos nem deduzir necessariamente que a promulgação de um regime de direitos de propriedade privada produziria resultados superiores em comparação com formas alternativas de direito de propriedade. [...]

Há indícios crescentes de que os arranjos institucionais desejáveis possuem um grande elemento de especificidade de contexto que surge das diferenças de trajetórias históricas, geografia, economia política ou outras condições iniciais. [...] Isso pode ajudar a explicar porque países em desenvolvimento bemsucedidos - China, Coreia do Sul e Taiwan, entre outros - combinaram quase sempre elementos heterodoxos com políticas ortodoxas. E pode explicar também porque persistem importantes diferenças institucionais entre os países avançados da América do Norte, da Europa Ocidental e o Japão - o papel do setor público, a natureza dos sistemas jurídicos, governança empresarial, mercados financeiros, mercados de trabalho e mecanismos de seguro social entre outros. [...]

Em consequência, há muito a ser aprendido sobre o que significa na realidade a melhoria da qualidade institucional. Gostaríamos de sugerir que se trata de uma área de pesquisa ampla e aberta. No momento, os estudos transnacionais são apenas um começo que apontam para a direção certa. ${ }^{191}$

Por fim, numa linha semelhante, em artigo recente intitulado "Institutions and Development: A View from Below", ${ }^{192}$ Rohini Pande e Christopher Udry declaram:

Em anos recentes, tivemos um renascimento notável e excitante do interesse pela análise empírica sobre como muitas instituições afetam o crescimento. O foco da recente produção de pesquisa está na exploração da variação transnacional em "qualidade institucional" para identificar se há um efeito causal das instituições sobre o crescimento. Esses trabalhos concluem que a qualidade institucional é um fator determinante significativo do desempenho de crescimento de um país.

Esses resultados são de importância fundamental para os economistas do desenvolvimento e formuladores de políticas, pois sugerem que a qualidade 
institucional pode fazer os países e os povos pobres a continuarem pobres. Porém, a interpretação econômica e as implicações políticas desses resultados dependem de compreender os canais específicos através dos quais as instituições afetam o crescimento, e os motivos para a mudança institucional ou sua falta. [...] Porém, sustentamos que essa literatura serviu ao seu propósito e está essencialmente completa. O número de variáveis disponíveis como variáveis instrumentais é limitado e sua grosseria impede uma análise mais minuciosa de determinados mecanismos causais das instituições para o crescimento. [...] Isso sugere que a agenda de pesquisa identificada pela literatura sobre instituições e crescimento será mais bem servida pela análise de muito mais micro-dados do que tem sido sua norma.

Em seguida, os autores ilustram a importância dessa microperspectiva com a descrição dos direitos de propriedade de terras em quatro países africanos (Gâmbia, República Democrática do Congo, Gana e Costa do Marfim), enfatizando a importância da distinção entre direitos de jure e de facto, a importância do direito consuetudinário, a heterogeneidade dos direitos da terra mesmo dentro de um mesmo país e o entrelaçamento de instituições políticas e contratuais. Pesquisas recentes sobre o império do direito e desenvolvimento têm sido feitas no mesmo espírito. ${ }^{193}$

Desse modo, embora pareça que do ponto de vista empírico exista um consenso cada vez mais firme de que as instituições, inclusive as jurídicas, são um importante fator determinante do desenvolvimento econômico (e, provavelmente, de outros aspectos do desenvolvimento), há muito menos consenso em relação ao que deva ser um conjunto de instituições ótimo.

Vale a pena observar também que esses estudos lançam pouca luz sobre as questões em torno dos meios de implementar qualquer conjunto dado de reformas jurídicas, inclusive a relativa importância dos atores locais e estrangeiros e as melhores maneiras de controlar os conflitos de interesse e os preconceitos que, supostamente, enfraquecem a eficácia de atores externos como o Banco Mundial. Há razões também para não aceitar os resultados desses estudos sem questionar. Várias críticas foram feitas às metodologias neles utilizadas. ${ }^{194}$

\section{CONClusão}

Embora pareça haver um consenso cada vez mais firme e empiricamente fundamentado de que as instituições são um importante fator determinante do desenvolvimento econômico - e, provavelmente, de outros aspectos do desenvolvimento -, há muito menos consenso em relação a quais instituições jurídicas são importantes, tendo em vista a existência de substitutos informais, como deve ser um conjunto ótimo dessas instituições, ou para aqueles países que carecem dessas instituições ótimas (qualquer 
que seja a definição disso), que forma um processo de reforma factível e eficaz poderia assumir e os respectivos papéis dos "de dentro" e dos "de fora” nesse processo.

Instituições ótimas em geral, e as jurídicas em particular, serão frequentemente moldadas por fatores específicos a determinadas sociedades, entre eles história, cultura e tradições políticas e institucionais antigas. Isso, por sua vez, implica algum grau de modéstia da parte da comunidade externa ao promover o império do direito ou outras reformas jurídicas nos países em desenvolvimento e, de forma correspondente, um papel maior para os "de dentro" com conhecimento local detalhado. Ademais, os pontos de referência para as reformas jurídicas em muitos países em desenvolvimento podem não ser os regimes jurídicos, substantivos ou institucionais, que prevalecem em determinados países desenvolvidos, mas arranjos mais apropriados que prevalecem em outros países em desenvolvimento que compartilhem aspectos importantes da história, da cultura e das tradições institucionais com países que empreendem tais reformas. ${ }^{195}$

Os formuladores de políticas precisam pensar com cautela e modéstia sobre quais são as vantagens comparativas que os "de fora", em especial aqueles do mundo desenvolvido, possuem para induzir ou ajudar os países em desenvolvimento a empreender reformas jurídicas, substantivas ou institucionais: dinheiro, obviamente; expertise puramente técnica, por exemplo, no planejamento de sistemas de informática para os tribunais ou a administração do registro de terras (e treinamento do pessoal local); talvez conhecimento da experiência comparativa com iniciativas semelhantes (bem ou malsucedidas) em outros países em desenvolvimento, inclusive interpretações adequadamente cautelosas das precondições para o sucesso ou o fracasso dessas iniciativas. Mas é difícil imaginar gente "de fora" assumindo efetivamente o papel de principais planejadores, ou promotores, ou defensores de tais iniciativas.

Concluímos então (seguindo o ponto de vista de Pande e Udry) que a próxima fronteira de pesquisa provavelmente pedirá uma análise muito mais trabalhosa $\mathrm{e}$ sensível ao contexto dos regimes jurídicos e instituições específicos (formais e informais) de determinadas sociedades e de suas reformas potenciais avaliadas em comparação com algum conjunto de objetivos amplos ou mais generalizáveis de desenvolvimento. Cremos que os teóricos do direito podem desempenhar um papel valioso nesse tipo de pesquisa, e devido a sua importância, os instamos a assumir esse desafio. 


\section{6 : A RELAÇÃO ENTRE DIREITO E DESENVOLVIMENTO: OTIMISTAS VERSUS CÉTICOS}

\section{NOTAS}

* Agradecemos a Helen Hershkoff, Stephen Humphreys, Kate Lauere, Mariana Prado e Frank Upham pelos úteis comentários e conversas. Kevin Davis reconhece agradecido o apoio do Filomen D'Agostino and Max E. Greenberg Research Fund da NYU School of Law.

1 Thomas Carothers. The Rule of Law Revival. In: Promoting the Rule of Law Abroad: In Search of Knowledge, p. 3 (Thomas Carothers, ed., 2006); ver também Brian Tamanaha, On The Rule of Law: History, Politics, Theory, 2004, p. 1-4.

2 David Trubek. The Rule of Law in Development Assistance: Past, Present and Future. In: The New Law and Economic Development: A Critical Appraisal, p. 74 (David M. Trubek \& Alvaro Santos, eds., 2006); Michael Trebilcock \& Ron Daniels. Rule of Law Reform and Development: Charting the Fragile Path of Progress (2008).

3 Ver em geral, Orly Lobel, The Paradox of Extralegal Activism: Critical Legal Consciousness and Transformative Politics, Harv. L. Rev. 120:938 (2007) (descreve e critica pressupostos dominantes sobre as limitações do direito como meio de efetuar mudança social nos Estados Unidos).

4 Carothers, nota 1 supra, p. 16

$5 \quad$ Idem.

6 Kenneth Dam. The Law-growth Nexus: The Rule of Law and Economic Development, 2006.

7 Trubek, nota 2 supra.

8 Ver David M. Trubek \& Alvaro Santos, Introduction: The Third Moment in Law and Development Theory and the Emergence of a New Critical Practice. In: The New Law and Economic Development, nota 2 supra. Nesse aspecto, o volume de Trubek e Santos é muito equívoco. Por exemplo, em outro lugar do ensaio, Trubek e Santos afirmam que o que distingue o momento intelectual atual é a proeminência da crítica. Idem, p. 8. Ao mesmo tempo, o artigo de Santos incluído no volume dedica-se a descrever e explicar a falta de consenso sobre o papel do direito no desenvolvimento justamente no interior do Banco Mundial. Ver em geral, Alvaro Santos, The World Bank's Uses of the "Rule of Law" Promise in Economic Development. In: The New Law and Economic Development, nota 2 supra, p. 253.

9 Trubek \& Santos, nota 8 supra. In: The New Law and Economic Development, nota 2 supra, p. 1, 15-17. Kerry Rittich sustenta a concepção mais holística do objetivo da reforma jurídica, agora "normalizado", observando que foi endossado por importantes teóricos como Amartya Sen, bem como por influentes atores, como o Banco Mundial. Kerry Rittich, The Future of Law and Development: Second-Generation Reforms and the Incorporation of the Social. In: The New Law and Economic Development, nota 2 supra, p. 203, 208. Ver também Rachel Kleinfeld, Competing Definitions of the Rule of Law. In: Promoting the Rule of Law Abroad, nota 1 supra, p. 31 (afirma que o império do direito deveria ser visto pelos reformadores como um fim e não como um meio)

10 Ver em geral, Duncan Kennedy, Three Globalizations of Legal Thought: 1850- 2000”. In: The New Law and Economic Development, nota 2 supra, p. 19. Cf Brian Tamanaha, "The Lessons of Law and Development Studies", Am. J. Int. L. 89:470, 470 (1995) ("Direito e Desenvolvimento têm sido um campo de estudo acadêmico há cerca de trinta anos").

11 Ver, e.g., J. S. Furnivall, Colonial Policy and Practice: A Comparative Study of Burma and Netherlands India (1956). Para referências adicionais à literatura sobre administração colonial ver John Henry Merryman, Comparative Law and Social Change: On the Origins, Style, Decline \& Revival of the Law and Development Movement, Am. J. Comp. L. $25: 457,468(1977)$

12 Scott Newton, The Dialectics of Law and Development. In: The New Law and Economic Development, nota 2 supra, p. $178,179,181$.

13 Rostow identificou cinco estágios: a sociedade tradicional, as precondições para a decolagem, a decolagem, o caminho para a maturidade, e a era do grande consumo de massa. Ver W.W. Rostow, Stages of Economic Growth: A Noncommunist Manifesto (1960) 
14 Tamanaha, nota 1 supra, p.10; Peter F. Klarén, Lost Promise: Explaining Latin American Underdevelopment. In: Promise of Development: Theories of Change in Latin America, p. 3, 11 (Peter F. Klarén \& Thomas J. Bossert, eds., 1986). Como diz Cyril Black, conhecido historiador e teórico da modernização: "Embora os problemas levantados por generalizações de uma base bastante estreita (os países agora modernos) devam ser admitidos, a definição de modernidade assume a forma de um conjunto de características supostamente aplicáveis a todas as sociedades. Essa concepção de modernidade, quando pensada como modelo ou tipo ideal, pode ser usada como um metro para medir qualquer sociedade”. Cyril Black, The Dynamics of Modernization: A Study in Comparative History, p. 68-75 (1966).

15 David M. Trubek, Toward A Social Theory of Law: An Essay on the Study of Law and Development, Yale L. J. $82: 44(1972)$

16 Elliot M. Burg, Law and Development: A Review of the Literature and a Critique of "Scholar in SelfEstrangement", Am. J. Comp. L. 25:492, 505-06 (1977).

\section{Idem.}

18 Burg, nota 16 supra, p. 492, 505, 506. Ver também Thomas Heller, An Immodest Postscript. In: Beyond Common Knowledge: Empirical Approaches to the Rule of Law (Erik Jensen \& Thomas Heller, eds., 2003).

19 David M. Trubek \& Marc Galanter, Scholars in Self-Estrangement: Some Reflections on the Crisis in Law and Development Studies in the United States, Wis. L. Rev. 1062, 1075-76 (1974) [N.E.: publicado em português como: TRUBEK, David M.; GALANTER, Marc. Acadêmicos auto-alienados: reflexões sobre a crise norte-americana da disciplina “direito e desenvolvimento". In: RODRIGUEZ, José Rodrigo (org.). O novo direito e desenvolvimento: presente, passado e futuro - textos selecionados de David M. Trubek. São Paulo: Saraiva, 2009) . Ver também Burg, nota 16 supra, p. 509-511. Como observaram Trubek e Galanter: "Os teóricos do desenvolvimento jurídico produziram avaliações críticas das escolas de direito na Ásia, África, e América Latina e afirmaram que ao treinar os juristas para pensar de modo mais instrumental, as escolas poderiam dar início a mudanças que diminuiriam a distância entre o desempenho atual da profissão jurídica e suas possibilidades desenvolvimentistas. Assim, propôs-se que as escolas de direito estudassem e explicassem a relação entre normas jurídicas específicas, doutrinas e procedimentos, de um lado, e metas de desenvolvimento nacional de outro, instando os estudantes a trabalhar para reformar as leis e instituições que não promovessem essas metas". www.tci.art.br/cor/efeito.htm

20 Lawrence Friedman, Legal Culture and Social Development, Law \& Society Rev., 4:29, 43 (1969).

21 Robert B. Seidman, The Communication of Law and the Process of Development, Wis. L. Rev. 686 (1972).

22 ade Channell, Lessons Not Learned About Legal Reform. In: Promoting the Rule of Law Abroad, nota 1 supra, p. 137, 139 (“Em muitos, senão na maioria dos casos, as lições do movimento Direito e Desenvolvimento simplesmente não foram aprendidas pelos profissionais da nova onda de reformas das últimas duas décadas").

23 Stephen Golub, The Legal Empowerment Alternative. In: Promoting The Rule of Law Abroad, nota 1 supra, p. 161.

24 Idem, p. 164, 165, 169-177. Ver também David Mednicoff, Middle East Dilemmas. In: Promoting The Rule of Law Abroad, nota 1 supra, p. 251, 268 (endossa a aplicação da abordagem de Golub no Oriente Médio).

25 Trubek \& Galanter, nota 19 supra.

26 Douglass North, Institutions, Institutional Change and Economic Performance (1990) [doravante Institutions, Institutional Change and Economic Performance]; North, Understanding the Process of Economic Change (2005) [doravante Understanding the Process of Economic Change]; World Bank, World Development Report 1997: The State in a Changing World.

27 Hernando de Soto, The Other Path: The Invisible Revolution in the Third World, p. 185 (1989).

28 Idem, p. 186.

29 Idem, p. 187. 
30 Ver, e.g., World Bank, World Development Report 2002: Building Institutions for Markets (2002); World Bank, World Development Report 1997: The State in a Changing World (1997); World Bank, World Development Report 1996: From Plan to Market (1996); World Bank, Doing Business in 2004: Understanding Regulation (2004).

31 Dam, nota 6 supra, p. 6.

32 Para exemplos de obras ilustrativas desse gênero, ver os documentos do Banco Mundial, citados na nota 30 supra, e Philip M. Nichols, A Legal Theory of Emerging Economies, Va. J. Int L. 39:229 (1999). Para outro exame útil da literatura, ver Frank B. Cross, Law and Economic Growth, Tex. L. Rev. 80:1737 (2002).

33 Ver, e.g., Robert Cooter, The Rule of State Law and the Rule of Law State: Economic Analysis of the Legal Foundations of Development. In: AnnualWorld Bank Conference on Development Economics, p. 212 (Michael Bruno \& Boris Pleskovic, eds., 1998); de Soto, nota 27 supra; Kathryn Hendley, Rewriting the Rules of the Game in Russia: The Neglected Issue of the Demand for Law, E. Eur. Const. Rev. 89 (1999); Douglass North, nota 26 supra, p. 89-91, 140, 141. Evidentemente, essas análises contemporâneas remontam às queixas de Trubek e Galanter sobre o "caráter etnocêntrico do modelo do legalismo liberal do direito na sociedade”. Ver David N. Trubek \& Marc Galanter, Scholars in Self-Estrangement: Some Reflections on the Crisis of Law and Development in the United States, Wis. L. Rev. 1062 (1974). Um expoente muito anterior de ideias similares foi Montesquieu, que declarou: "[As leis] deveriam ser adaptadas de tal modo ao povo para o qual são elaboradas que só por um grande acaso as de uma nação serviriam para outra”. Ver Charles de Secondat, barão de Montesquieu, The Spirit of The Laws, p. 6 (Book I) (Anne M. Cohler et al., trad. e eds., 1989).

34 Ver especialmente Cooter, nota 33 supra e de Soto, nota 27 supra.

35 Katharina Pistor, The Standardization of Law and Its Effect on Developing Economies, Am. J. Comp. L. 50:101 (2002); Dan Berkowitz, Katharina Pistor \& Jean-François Richard, Economic Development, Legality, and the Transplant Effect, Eur. Econ. Rev. 47:165 (2003).

36 Dam, nota 6 supra, p. 24

37 Idem, p. 224.

38 Heinz Klug, Constituting Democracy: Law, Globalism and South Africa's Political Reconstruction, p. 66 (2000). Ver também Carothers, nota 1 supra, p. 8 (descreve as reformas constitucionais na Europa Oriental e na América Latina).

39 Klug, nota 38 supra.

40 Oona Hathaway, Do Human Rights Treaties Make a Difference?, Yale L. J. 111:1936 (2002).

41 Kleinfeld, nota 9 supra, p. 34-47 (explica porque o respeito a normas como igualdade e direitos humanos e o império do direito são fins que valem a pena); Santos, nota 8 supra, p. 253, 261-263, 265-266 (resume as alegações de que o império do direito é intrinsecamente valioso).

42 Daniel A. Farber, Rights as Signals, J. Legal Stud. 31:83 (2002).

43 Dam, nota 6 supra, p. 41.

44 Para uma exposição recente desse ponto de vista e uma análise da literatura pertinente, ver Jagdish $\mathrm{N}$. Bhagwati, Democracy and Development: Cruel Dilemma or Symbiotic Relationship?, Rev. Dev. Econ. 6:151-62 (2002); para uma discussão de porque a democracia exige mais freios e contrapesos do que apenas eleições competitivas periódicas, ver Paul Collier, The Bottom Billion, p.146-149 (2007).

45 Ver, e.g., Surjit Bhalla, Freedom and Economic Growth: A Virtuous Cycle? In: Democracy's Victory and Crisis, p. 195 (Axel Hadenius, ed., 1997).

46 Amartya Sen, Resources, Values and Development (1984); Amartya Sen \& Jean Drkze, Hunger and Public Action (1989); Amartya Sen, Development as Freedom (1999). 
47 Immanuel Kant, Perpetual Peace. In: The Enlightenment:A Comprehensive Anthology, p. 784 (Peter Gay, ed., 1974); Michael Doyle, Kant, Liberal Legacies and Foreign Affairs, Part 1, Phil. \& Pub. Aff. 12:323 (1983).

48 Para visões gerais do debate empírico, ver Adam Przeworski \& Fernando Limongi, Political Regimes and Economic Growth, J. Econ. Persp. 7:51 (1993); Adam Przeworski et al., Democracy and Development: Political Institutions and Well-Being in the World 1950-1990 (2000); Bhagwati, nota 44 supra.

49 OLSON, Mancur. Power and Prosperity: Outgrowing Communist and capitalist dictatorships New York: Basic Books, 2000.

50 Idem, p. 6, 7.

51 Idem, p. 7-12.

52 Cf. Avinash Dixit, Gene M. Grossman \& Faruk Gul, The Dynamics of Political Compromise, J. Pol. Econ. 108:531 (2000) (a perspectiva de uma sequência indefinida de mudanças razoavelmente frequentes no poder também pode dar a líderes democraticamente eleitos um incentivo para cooperar com oponentes políticos na esperança de receber tratamento recíproco quando estiverem fora do poder). Outros estudiosos observaram - e Olson prontamente admite que as democracias são vulneráveis às pressões de grupos de interesse, ignorância e desinformação dos eleitores e formas majoritárias de opressão das minorias, e que alguns regimes democráticos são provavelmente fracos, instáveis ou corruptos. Mancur Olson, Dictatorship, Democracy and Development, 87 Am. Pol. Sci. Rev. 87:567, 571 (1993). Ver também Thomas Carothers, The End of the Transition Paradigm, J. of Democracy 13:5 (2002).

53 Dani Rodrik, One Economics, Many Recipes: Globalization, Institutions and Economic Growth, cap. 5 (2007) (Institutions for High-Quality Growth).

54 Charles de Montesquieu, The Spirit of the Laws, cap. XI e XII. Ver também The Federalist n. 51 (James Madison).

55 James D. Gwartney \& Randall G. Holcombe, Economic Freedom, Constitutional Structure and Growth in Developing Countries; In: Institutions and Collective Choice in Developing Countries, p. 33, 39 (Mwangi Kimenyi \& John Mukum Mbaku, eds., 1999); Jean-Jacques Laffont \& Mathieu Meleau, Separation of Powers and Development, 64 J. Dev. Econ. 64:129 (2001). Ver também Albert Breton, Competitive Governments: An Economic Theory Of Politics and Public Finance (1996); Torsten Persson et al., Separation of Powers and Political Accountability, Q.J. Econ. 112:1163 (1997); Roumeen Islam \& Claudio Montenegro, What Determines The Quality of Institutions? (2002); Daniel Lederman et al, Accountability and Competition: Political Institutions Matter (2001).

56 Ver, e.g., Martin Shapiro, Courts: A Comparative and Political Analysis (1981).

57 Douglass North \& Barry Weingast, Constitutions and Commitment: The Evolution of Institutions Governing Public Choice in Seventeenth Century England, J. Econ. Hist. 49:803, 831 (1989).

58 Idem.

59 Matthew C. Stephenson, “When the Devil Turns...” The Political Foundations of Independent Judicial Review, J. Legal Stud. 32:59 (2003).

60 Ver em geral Breton, nota 55 supra.

61 Barry Weingast, The Economic Role of Political Institutions: Market Preserving Federalism and Economic Development, J. L. Econ. \& Org. 11:1 (1995).

62 Idem, p. 9.

63 Dam, nota 6 supra, p. 107 ("Embora muitos países acreditem que a estrutura de seus governos baseie-se naquele princípio [separação dos poderes], o conteúdo do princípio difere entre países a tal ponto que duas versões totalmente incompatíveis desse princípio existem no mundo.”), p. 111-118 (discutindo a "independência comportamental” de juízes em vários países). 
64 Dam, nota 6 supra, p. 106-111.

65 Idem, p. 111-118.

66 Ver em geral Timothy Besley et al., Mass Media and Political Accountability, primeira versão de capítulo para The Right to Know: Institutions and the Media 6 (World Bank); Simeon Djankov, Caralee McLeish, Tatiana Nenova \& Andrei Shleifer, Who Owns the Media?, manuscrito (2001).

67 Amartya Sen \& J. Dreze, The Political Economy of Hunger (1990).

68 Idem.

69 Ver, e.g., Aymo Brunetti \& Beatrice Weder, A Free Press is Bad News for Corruption, (Working Paper: University of Basel, April, 1999); ver também Islam \& Montenegro, nota 55 supra.

70 Besley et al., nota 66 supra, p. 6

71 Ver em geral Antony Anghie, Imperialism, Sovereignty and The Making of International Law, p.196-244 (2005).

72 Rodrik, One Economics, Many Recipes, nota 53 supra, cap. 8 (The Global Governance of Trade As if Development Mattered) (recomenda que a OMC seja vista como uma instituição que permite aos países em desenvolvimento autonomia para realizar as inovações institucionais exigidas para estimular o crescimento econômico); Kevin E. Davis, How to Make the Doha Round a Genuine Development Round, Am. Soc. of Int. L. Proceedings of the Annual Meeting. 100:226 (2006) (identifica canais através dos quais as reformas do regime da OMC poderiam influenciar instituições jurídicas nacionais); Collier, nota 44 supra, cap. 9 (defende que várias cartas internacionais estabeleçam normas para a conduta governamental em algumas áreas).

73 Aymo Brunetti \& Beatrice Weder, More Open Economies Have Better Governments, 18 (Working Paper: University of Saarland Economic Series 9905, 1999); Silvio Borner, Aymo Brunetti \& Beatrice Weder, Political Credibility and Economic Development, p. $91-95$ (1995). Ver também Islam \& Montenegro, nota 55 supra; Daniel Treisman, The Causes of Corruption: A Cross-National Study, J. Pub. Econ. 76:399 (2000); cf. Dani Rodrik et al., Institutions Rule: The Primacy of Institutions over Geography and Integration in Economic Development, J. Econ. Growth 9:131 (2004).

74 Brunetti \& Weder, nota 73 supra, p. 18

75 Idem

76 Ver Carothers, nota 1 supra, p. 3, 7 ("Embora sua capacidade de operar maravilhas tenha sido exagerada, a conveniência do império do direito está clara.”). Tanto Upham como Santos atribuem essa concepção ao Banco Mundial, citando textos de seu ex-conselheiro geral e vice-presidente sênior, Ibrahim Shihata. Ver Santos, nota 8 supra, p. 269-273; Frank Upham, Mythmaking in the Rule of Law Orthodoxy. In: Promoting the Rule of Law Abroad, nota 1 supra, p. 77-79. Para uma coletânea dos textos de Shihata, ver Ibrahim F.I. Shihata, Complementary Reform: Essays on Legal, Judicial and Other Institutional Reforms Supported by The World Bank (1997).

77 Competing Definitions of the Rule of Law. In: Promoting the Rule of Law Abroad, p. 31

78 Ver em geral Santos, nota 8 supra, p. 259-266 (discute concepções alternativas do império do direito e sua relação com o desenvolvimento).

79 Ver, e.g., Lon L. Fuller, The Morality of Law, p. 39 (ed. rev. 1969).

80 Idem, p. 200-224.

81 Joseph Raz, The Rule of Law and its Virtue. In: The Authority of Law: Essays On Law and Morality, p. 210-229 (1979). Para uma fusão similar de componentes formais e institucionais no processo de definição do império do direito, ver Robert S. Summers, A Formal Theory of the Rule of Law, Ratio Juris 6:127-42 (1993). Summers oferece uma especificação mais elaborada dos componentes institucionais do império do direito. 
82 Idem, p. 226

83 Ver Tamanaha, nota 10 supra; ver também, Tamanaha, nota 1 supra.

84 Idem, p. 476

85 Fuller, nota 79 supra, p. 44

86 Tamanaha, nota 10 supra, p. 476

87 Kleinfeld, nota 9 supra, p. 61.

88 Dam parece considerar as reformas jurídicas específicas que recomenda um meio de alcançar o império do direito, que ele define de modo muito parecido com os teóricos do direito discutidos nesta subsseção. Ver Dam, nota 6 supra, p. 13-17, 24. Nós o caracterizamos como otimista porque ele, em última análise, endossa o pressuposto de que as instituições jurídicas são importantes como base válida para a formulação de políticas. Dam, nota 6 supra, p. 230,231

89 Parte III, adiante.

90 Trubek \& Galanter (1974), nota 19 supra.

91 John Henry Merryman, Comparative Law and Social Change: On the Origins, Style, Decline \& Revival of the Law and Development Movement, Am. J. Comp. L. 25:457, 459, 460 (1977).

92 Trubek \& Galanter, nota 19 supra.

93 Idem, p. 1078, 1079

94 Idem, p. 1076

95 Ver, e.g., David Kennedy, The "Rule of Law", Political Choices, and Development Common Sense. In: The New Law and Economic Development, nota 2 supra, p. 173 ("as estratégias de desenvolvimento exigem um exame detalhado das escolhas distribucionais efetuadas por várias regras e regimes jurídicos para determinar, da melhor maneira possível, seu provável impacto sobre o crescimento e o desenvolvimento"); Rittich, nota 9 supra, p. 228 ("o fato de a agenda do desenvolvimento ter sido reformulada para incluir o social quase não se reflete na agenda jurídica central e institucional”); Trubek \& Santos, nota 8 supra, p. 16 ("Um objetivo muito central de nosso esforço tem sido recolocar as questões of distribucionais na agenda do desenvolvimento.”).

96 Golub, nota 23 supra, p. 109-111.

97 Mednicoff, nota 22 supra, p. 251, 262-266.

98 Para uma articulação eloquente e persuasiva da importância mais geral do conhecimento local na formulação de políticas, ver James C. Scott, Seeing Like A State: How Certain Schemes to Improve the Human Condition Have Failed (2002).

99 Santos, nota 8 supra, p. 290, 291.

100 Idem, p. 297, 298.

101 Idem, p. 296, 297.

102 Golub, nota 23 supra, 127-131 (discute o papel dos incentivos criados por estruturas burocráticas, interesses próprios e vieses dos profissionais do direito); Laure-Helène Piron, Time to Learn, Time to Act in Africa. In: Promoting the Rule of Law Abroad, nota 1 supra, p. 275, 294-297 (identifica problemas colocados por incentivos gerados internamente para aprovar projetos ruins, falta de experiência pertinente da parte dos especialistas do setor da justiça designados para projetos de desenvolvimento e conflitos entre doadores). 


\section{2 : A RELAÇÃO ENTRE DIREITO E DESENVOLVIMENTO: OTIMISTAS VERSUS CÉTICOS}

103 Kleinfeld, nota 41 supra, p. 56-58. Ver também Channell, nota 22 supra, p. 156 (discute vários motivos para que os doadores possam patrocinar reformas jurídicas).

104 Channell, nota 22 supra, p. 149-156.

105 Piron, nota 102 supra, p. 298. Para uma discussão geral das deficiências das instituições que fornecem ajuda ao desenvolvimento, ver William Easterly, White Man's Burden: Why the West's Efforts to Aid the Rest Have Done so Much Ill and so Little Good (2006).

106 Simeon Djankov et al., Courts, Q.J. Econ. 118:453 (2003) (mostra a relação entre origem legal e aplicação de contratos); Rafael La Porta et al., Legal Determinants of External Finance, J. Fin. 52:1131 (1997) (origem legal e proteção de investidores); Rafael La Porta et al., Law and Finance, J. Pol. Econ. 106:1113 (1998) (o mesmo); Simeon Djankov et al., The Regulation of Entry, Q.J. Econ. 117:1 (2002) (origem legal e regulamentação de entrada); Juan Botero et al., The Regulation of Labor, Q.J.Econ. (2004) (origem legal e regulamentação de mão-de-obra); Paul G. Mahoney, The Common Law and Economic Growth: Hayek Might be Right, J. of Legal Stud. 30:503 (2001) (origem legal e crescimento econômico). Cf Daron Acemoglu et al., The Colonial Origins of Comparative Development: An Empirical Investigation, Am. Econ. Rev. 91:1369 (2001) (conclui que a correlação entre herança jurídica e medidas de qualidade institucional desaparece quando se leva em conta o impacto das variações nas políticas das potências colonizadoras); Daniel Berkowitz et al., Economic Development, Legality, and the Transplant Effect, Eur. Econ. Rev. 47:165 (2003) (conclui que a correlação entre herança jurídica e medidas de qualidade institucional desaparece quando se leva em conta o grau do transplante com adaptação no século XIX).

107 Em linha semelhante, Olson afirma que "a autocracia é evitada e a democracia é permitida pelos acidentes históricos que deixam um equilíbrio de poder", ou um impasse - uma dispersão de força e recursos que torna impossíve para qualquer líder ou grupo dominar todos os outros. Nessas circunstâncias, os líderes dos grupos competidores têm um incentivo para criar arranjos institucionais que impedem que algum grupo monopolize o poder. (Olson aponta também outras duas condições necessárias para que surja uma democracia. Para evitar o surgimento de "miniautocracias", os grupos em competição devem estar dispersos por toda a região. Também não deve haver qualquer possibilidade iminente de conquista por regimes vizinhos.) Essa concepção parece dizer que uma mudança política séria depende de acidentes da história. Olson, nota 49 supra, p. 33, 573.

108 Ver Brian Arthur, Self-Reinforcing Mechanisms in Economics. In: The Economy as an Evolving Complex System (Phillip Anderson et al., eds., 1988); W. Brian Arthur, Competing Technologies, Increasing Returns and Lock-in by Historical Events, Econ.J. 99:116 (1989); Paul David, Clio and the Economics of QWERTY, Am. Econ. Rev. 75:332 (1985).

109 Institutions, Institutional Change and Economic Performance, nota 26 supra; Understanding the Process of Economic Change, nota 26 supra.

110 Institutions, Institutional Change and Economic Performance, nota 26 supra, p. 99.

111 Idem, p. 101

112 World Bank, nota 26 supra.

113 Thomas Carothers, The End of the Transition Paradigm, J. Democracy 13:5 (2002).

114 Daniel Kaufmann \& Aart Kraay, Growth Without Governance, (World Bank Policy Research Working Paper No. 2928 July 2002)

115 Piron, nota 102 supra, p. 281, 282

116 Idem.

117 Sen, nota 46 supra, p. 48.

118 Ver, Kleinfeld, nota 41 supra, p. 55, 56 (Alcançar os objetivos do império do direito exige mudança política e cultural, não apenas institucional.”); Matthew Stephenson, A Trojan Horse in China. In: Promoting the Rule of Law Abroad, 
nota 1 supra, p. 191 (afirma que a elite política da China provavelmente frustrará ou cooptará as reformas jurídicas que ameacem seus interesses); Matthew Spence, The Complexity of Success in Russia. In Promoting the Rule of Law Abroad nota 1 supra, p. 217 (atribui o sucesso das reformas apoiadas pelos EUA na Rússia a condições políticas propícias); Mednicoff, nota 24 supra, p. 269 (observa que o sucesso de reformas no Oriente Médio dependerá da cooperação das elites políticas); Piron, nota 102 supra, p. 287-290 (a ajuda ao império do direito deve ser sensível ao contexto político); Lisa Bhansali \& Christina Biebesheimer, Measuring the Impact of Criminal Justice Reform in Latin America. In: Promoting the Rule of Law Abroad, nota 1 supra, p. 301, 303, 304 (observa que as reformas na América Latina estiveram associadas aos esforços para consolidar a transição política do autoritarismo para a democracia).

119 Ver Kennedy, nota 95 supra, p. 95 (examina as mudanças no discurso dos especialistas sobre política de desenvolvimento desde 1945, e observa como o discurso contemporâneo do direito e desenvolvimento obscurece questões políticas que subjazem às escolhas de normas e regimes jurídicos); Kerry Rittich, The Future of Law and Development: Second Generation Reforms and the Incorporation of the Social. In: em The New Law and Economic Development, nota 2 supra, p. 248, 252 (enfatiza que a tarefa de reabilitar as reformas institucionais que promovem a justiça social é uma tarefa política).

120 Dam, nota 6 supra, p. 69.

121 Ver, e.g., Mahmood Mamdani, Citizen and Subject: Contemporary Africa and the Legacy of Late Colonialism (1996) (remonta os traços despóticos dos governos africanos pós-coloniais ao despotismo colonial); Matthew Lange, British Colonial Legacies and Political Development, World Dev. 32:905 (2004) (o mesmo).

122 Daron Acemoglu et al., nota 106 supra.

123 À medida que fossem fornecidas descrições dessas reformas, elas incluiriam restrições aos investimentos estrangeiros e políticas de substituição de importações; reforma de regimes de propriedade da terra opressivos; concessão aos trabalhadores de um papel significativo na direção das empresas; cooperativas de trabalhadores e lavradores; empresas estatais e criação de direitos econômicos e sociais, isto é, direitos constitucionalmente garantidos a educação, saúde, alimentação, moradia, emprego e renda. Ver em geral Samir Amin, Maldevelopment: Anatomy of a Global Failure (1990), Socialist Models of Development, Special Issue of World Dev. (1981); Adamantia Pollis, Human Rights, Third World Socialism and Cuba, World Dev. 9:1005 (1981).

124 Outra importante escola de pensamento, da qual Jared Diamond e Jeffrey Sachs talvez sejam os proponentes modernos mais conhecidos, examina os modos como a geografia influencia o econômico através de seu impacto sobre a produtividade agrícola e industrial, em vez da qualidade institucional. Assumindo uma perspectiva de longo prazo, Diamond sugere que a geografia determinou a produtividade agrícola e a relativa suscetibilidade às doenças ao influenciar a disponibilidade de espécies animais e vegetais adequadas à domesticação. Ver Jared Diamond, Guns, Germs and Steel: The Fate of Human Societies (1997). Ao tratar da história mais recente, Sachs e seus coautores afirmam que os países situados nos trópicos e que possuem uma alta densidade populacional em áreas que distam mais de cem quilômetros da costa sofrem uma grave desvantagem natural. Eles afirmam que as regiões tropicais suportam mais doenças e têm produtividade agrícola baixa. Por sua vez, a proximidade da população de um país da costa marítima é um fator determinante importante de sua capacidade de promover o crescimento econômico através da exportação de bens mão-de-obra intensiva. Ver John L. Gallup et al., Geography and Economic Growth, Int. Reg. Sci. Rev. 22:179 (1999). Não tratamos em detalhes dessas teorias da influência da geografia no desenvolvimento porque há provas transnacionais convincentes de que na era moderna, a geografia influenciou o desenvolvimento principalmente através de seu impacto sobre a qualidade institucional. Ver William Easterly \& Ross Levine, Tropics, Germs and Crops: How Endowments Influence Economic Development, J. Monetary Econ. 50:3 (2003); Rodrik et al., nota 73 supra.

125 Kenneth L. Sokoloff \& Stanley L. Engerman, History Lessons: Institutions, Factor Endowments, and Paths of Development in the New World, J. Econ. Persp. 14:217 (2000); Stanley L. Engerman \& Kenneth L. Sokoloff, Factor Endowments, Inequality, and Paths of Development Among New World Economies, (NBER Working Paper No. 9259, Out. 2002).

126 Essa argumentação é prenunciada pela afirmação anterior de Baldwin de que as indústrias extrativas de capital intensivo em que a propriedade tende a ser muito concentrada e que dependem de uma grande classe de trabalhadores não especializados de baixa renda costumam gerar poucas "ligações" para frente ou para trás, no sentido de que geram pouca demanda para os inputs locais ou serviços de processamento, pouco gasto adicional em bens de consumo produzidos 


\section{4 : A RELAÇÃO ENTRE DIREITO E DESENVOLVIMENTO: OTIMISTAS VERSUS CÉTICOS}

no lugar e receitas tributárias limitadas. E o que é mais importante para nossos propósitos, Baldwin sugeriu que os grupos dominantes dessas sociedades tendem a erguer "barreiras sociais e econômicas" para limitar a mobilidade para cima do grupo de baixa renda. Ver R. E. Baldwin, Patterns of Settlement in Newly Settled Regions, Manchester School of Soc. \& Econ. Stud. 24:161 (1956).

127 Richard M. Auty, Natural Resource Endowment, The State, and Development Policy, J. Int. Dev. 9:651 (1997); Richard M. Auty \& Alan H. Gelb, Political Economy of Resource-Abundant States. In: Resource Abundance and Economic Development, p. 3-10 (Richard M. Auty, ed., 2001). Ver também Jeffrey D. Sachs \& Andrew M. Warner, Natural Resource and Economic Development: the Curse of Natural Resources, Eur. Econ. Rev. 45:827 (2001); Collier, nota 44 supra; Escaping the Resource Curse (Macartan Humphreys et al., eds., 2007) (fornece provas de que países bem dotados de recursos naturais apresentam com frequência taxas relativamente baixas de crescimento econômico). Auty observa que um Estado predatório também pode surgir em uma sociedade camponesa etnicamente dividida.

128 William Easterly, Can Institutions Resolve Ethnic Conflict, Econ. Dev. \& Cult. Change 49:687 (2001); Patrick Chabal \& Jean-Pascal Daloz, Africa Works: Disorder as Political Instrument (1999).

129 O impacto adverso da diversidade étnica sobre a produção de bens públicos também pode se manifestar, por exemplo, na incapacidade de entrar em acordo sobre uma língua comum de ensino nas escolas, sobre as comunidades que devem receber investimentos em estradas, escolas, saúde e telecomunicações, ou sobre os setores para os quais deve ser canalizada a ajuda industrial. Alberto Alesina, et al., Public Goods and Ethnic Divisions, Q.J. Econ. 114:1243 (1999).

130 Guillermo O'Donnell, Polyarchies and the (Un) Rule of Law in Latin America. In: The (UN) Rule of Law and the Underprivileged in Latin America, p. 303 (Juan Mendez, Guillermo O’Donnell \& Paulo Sérgio Pinheiro, eds., 1998). Ele afirma também que a desigualdade econômica solapa o respeito pelo império do direito ao limitar a capacidade dos membros mais pobres da sociedade de exercer seus direitos. Ver também Seymour Martin Lipset, Political Man: the Social Bases of Politics, p. 51 (1963).

131 Alberto Alesina \& Roberto Perotti, Income Distribution, Political Instability and Investment, Eur. Econ. Rev. 40:1203, 1204 (1996)

132 Amy Chua, Markets, Democracy and Ethnicity: Toward a New Paradigm for Law and Development, Yale L.J. 108:1 (1998); Amy L. Chua, The Paradox of Free Market Democracy: Rethinking Development Policy, Harv. Int. L. J. 41:287 (2000); Amy Chua, World on Fire: How Exporting Free Market Democracy Breeds Ethnic Hatred and Global Instability (2003).

133 A instabilidade política é um importante componente das medidas mais populares de qualidade institucional, com base na suposição de que ela tende a atuar como dissuasória do investimento. Ver Alesina \& Perotti, nota 131 supra.

134 Ver Dam, nota 6 supra, p. 60-69 (examina a teoria e os indícios de relações entre cultura, direito e desenvolvimento econômico); Kleinfeld nota 9 supra, p. 55, 56 (a cultura pode influenciar a reforma jurídica); Channell, nota 22 supra, p. 146-148 (o mesmo); Stephen Golub, A House Without a Foundation. In: Promoting the Rule of Law Abroad, nota 1 supra, p. 116 (o mesmo); Kennedy, nota 95 supra, p. 155, 164 (a corrente dominante dos teóricos do desenvolvimento acredita agora que a cultura é importante); Rittich, nota 9 supra (as instituições financeiras internacionais estão interessadas agora na relação entre cultura, direito e crescimento econômico). Cf Upham, nota 76 supra, p. 97, 98 (mostra que reformas jurídicas deliberadas, em vez da cultura, explicam a variação de níveis do litígio japonês).

135 Dam, nota 6 supra, p. 60-69. Uma parte da literatura examinada por Dam é discutida adiante.

136 Ver em geral Culture Matters: How Values Shape Human Progress (Lawrence E. Harrison \& Samuel P. Huntington, eds., 2000); Lawrence Harrison, The Central Liberal Truth: How Politics Can Change a Culture and Save It From Itself (2000).

137 Para uma interpretação detalhada recente das concepções de Max Weber, ver Chantal Thomas, Max Weber, Talcott Parsons and the Sociology of Legal Reform, Minn. J. Int. L. 15:383 (2006).

138 David Landes, Culture Makes All the Difference. In: Culture Matters, nota 136 supra. 
139 Harrison, nota 136 supra, p. 36-47; para um espectro muito mais eclético de ideias sobre a relação entre cultura e desenvolvimento, ver os artigos coletados em Culture and Public Action (Vijayendra Rao \& Michael Walton, eds., 2004).

140 Ver Rafael La Porta et al., The Quality of Government, J. L. Econ. \& Org. 15:222 (1999); Daniel Treisman, The Causes of Corruption: A Cross-National Study, J. Pub. Econ. 76:399 (2000).

141 Robert Putnam, Making Democracy Work: Civic Traditions in Modern Italy, p. 15 (1993).

142 Idem, p. 88.

143 Idem, p. 167. Putnam afirma que é difícil manter as normas de reciprocidade em sociedades estruturadas verticalmente. Os membros dos escalões mais altos não temerão punições de seus subordinados, uma vez que é improvável que tal punição venha a acontecer. Em consequência, a exploração dos subordinados será mais frequente. Por sua vez, os próprios subordinados, que dependem do favor de seus superiores, "não sentem obrigação para com ninguém" e assim é mais provável que tenham comportamentos oportunistas entre eles. Putnam afirma que uma estrutura horizontal é mais conducente às normas de reciprocidade que caracterizam uma sociedade cívica. Desse modo, teoriza que quanto maior o número de redes horizontais ligando os membros da comunidade, maiores as perdas sofridas por um membro que abandona uma transação individual. Putnam nota 141 supra, p. 173-175. Ver também, Ronald J. Oakerson, Reciprocity: A Bottom-Up View of Political Development. In: Rethinking Institutional Analysis and Development, p. 141 (Vincent Ostrom, David Feeny \& Hartmut Picht, eds., 1988).

144 Idem, p. 172.

145 Putnam, nota 141 supra, p. 182.

146 Ver Frances Fukuyama, Social Capital, Civil Society and Development, ThirdWorld Q. 22:7 (2001).

147 Ver, e.g., Gert H. Hofstede, Culture's Consequences: International Differences In Work-related Values (1980) (compara culturas em termos de evitação da incerteza, distância do poder (uma medida de preferência pelo exercício da autoridade autocrática em oposição a consultiva), individualismo e masculinidade); Shalom H. Schwartz, Cultural Value Differences: Some Implications for Work, Applied Psychol. Int. Rev. 48:23 (1999) (compara culturas em termos do respeito à autonomia em oposição a enraizamento, hierarquia em oposição a igualitarismo, e domínio em oposição a harmonia). Nessa literatura, os valores que constituem uma cultura foram definidos como "as ideias abstratas implicita ou explicitamente compartilhadas sobre o que é bom, correto e desejável numa sociedade”. Amir Licht et al., Culture Rules: The Foundations of the Rule of Law and Other Norms of Governance, (documento de trabalho inédito datado de 09.06.2002, disponível em: < http://www.ssrn.com >), citando Robin M. Williams, American Society: A Sociological Interpretation ( $3^{\mathrm{a}}$ ed., 1970).

148 Licht et al., nota supra, <CITE_Ref67480378”>.

149 Henry Sumner Maine, Ancient Law: Its Connection with the Early History of Society, and Its Relation to Modern Ideas, p. $75-78$ (1861); Friedrich Karl Von Savigny, Of theVocation of Our Age for Legislation and Jurisprudence, p. 48 (Abraham Hayward, trad., 1831).

150 Alan Watson, Society and Legal Change, p. 8 (1977).

151 Ver, e.g., Alan Watson, Legal Change: Sources of Law and Legal Change, U. Pa. L. Rev. p. 1121, 1146, 1147 (1983).

152 Paul Mahoney, The Common Law and Economic Growth: Hayek Might be Right, J. Legal Stud. 30:503 (2001).

153 Mas ver DanielTreisman, The Causes of Corruption: A Cross-National Study, J. Pub. Econ. 76:399 (2000) (sugere que a cultura jurídica é determinada pela herança colonial e não apenas pelo fato de um país adotar o direito consuetudinário ou civil).

154 Cf Daniel Kaufmann, Governance Redux: The Empirical Challenge (2004) (contesta conclusões de que existe uma relação forte entre herança jurídica e desenvolvimento econômico). 


\section{6 : A RELAÇÃO ENTRE DIREITO E DESENVOLVIMENTO: OTIMISTAS VERSUS CÉTICOS}

155 Thomas Heller, An Immodest Postscript. In: Beyond Common Knowledge (Erik Jensen \& Thomas Heller, eds., 2003), nota 18 supra.

156 Ver colaborações em Rao \& Walton, nota 139 supra, esp. Amartya Sen, How Does Culture Matter?

157 Gillian K. Hadfield, The Levers of Legal Design: Institutional Determinants of the Quality of Law, J. Comp. Econ. $36: 43(2008)$.

158 Para um exame da literatura, ver Sally Engle Merry, Legal Pluralism, Law \& Soc.. Rev. 22:869 (1988).

159 Ver Tom Ginsburg, Does Law Matter for Economic Development? Evidence from East Asia, Law \& Soc. Rev. 34:829 (2000); Amanda Perry, Effective Legal Systems and Foreign Direct Investment: In Search of the Evidence, Int. Comp. L. Q. 49:779 (2000); Amanda Perry, The Relationship Between Legal Systems and Economic Development: Integrating Economic and Social Approaches, J.L.\&Soc. 29:282 (2002); Amanda Perry-Kessaris, Finding and Facing Facts About Legal Systems and Foreign Direct Investment in South Asia, Legal Stud. 23:649 (2003); Upham, nota 76 supra; Kanishka Jayasuriya, Introduction: A Framework for the Analysis of Legal Institutions in East Asia. In: Law, Capitalism, and Power in Asia, p. 7 (Kanishka Jayasuriya, ed., 1999).

\section{Idem.}

161 Ver Upham, nota 76 supra.

162 Minxin Pei, China's Trapped Transition: The Limits of Developmental Autocracy (2006); Michael Trebilcock \& Jing Leng, The Role of Formal Contract Law and Enforcement in Economic Development, Va. L. Rev. 92:1517, 1554-65 (2006) (e referências); Dam, nota supra <CITE_Ref188857172”>

163 Ver, e.g., Stewart Macaulay, Non-Contractual Relations in Business: A Preliminary Study, Am. Soc. Rev. 28:55 (1963); Robert Ellickson, Order without Law: How Neighbors Settle Disputes (1991); Lisa Bernstein, Opting Out of the Legal System: Extralegal Contractual Relations in the Diamond Industry, J. Legal Stud. 21:115 (1992); Sally Merry chama essa linha de pensamento de "novo pluralismo legal," distinguindo-a do "pluralismo legal clássico" que se centrava no pluralismo jurídico em ex-colônias europeias. Ver Merry, nota 158 supra.

164 Douglass C. North, The New Institutional Economics and Third World Development. In: The New Institutional Economics and ThirdWorld Development, p. 17 (J. Harriss et al., eds., 1995).

165 Ver o ensaio-resenha de Richard McAdams \& Eric Rasmusen, Norms in Law and Economics. In: Handbook of Law and Economics (Mitchell Polinsky \& Steven Shavell, eds., 2007); Michael Trebilcock \& Paul Erik Veel, Property Rights and Development: The Contingent Case for Formalization, U. Toronto, Legal Studies Research Paper n. 08-10.

166 Para citar apenas um exemplo, embora Weingast concorde que os supostos benefícios das restrições federalistas não signifiquem nada, a não ser que os atores políticos evitem violar essas restrições, ele alega que é possível que o federalismo seja “autoimpositivo." Ele sustenta que é improvável que até mesmo os atores políticos poderosos tentem violar uma restrição constitucional se houver a probabilidade de uma proporção significativa de a população se mobilizar e punir as violações. Isso é mais provável de ocorrer se houver um consenso entre os cidadãos de que a restrição é legítima, estando implícito que os cidadãos têm opiniões relativamente similares sobre os limites apropriados do governo e que a sociedade é suficientemente coesa para que seus membros estejam dispostos a punir violações que só afetam outros grupos também. Ver Weingast, nota 61 supra, p. 10. Esse aspecto do raciocínio de Weingast sugere que ele é cético em relação ao papel das normas jurídicas na sustentação do federalismo. Para sermos justos, porém, a análise de Weingast contém também um componente mais otimista quando ele afirma que, mesmo que não sejam impostas por instituições formais, as normas jurídicas ainda podem ajudar a criar o necessário consenso social: "Um conjunto de regras públicas apropriadamente escolhidas encarnado numa constituição pode servir de dispositivo de coordenação porque propicia a cada cidadão uma maneira similar de julgar e reagir à ação do Estado”. Idem, p. 15. Com efeito, criando um conjunto de pontos focais de ampla concordância. Weingast imagina assim que uma interação entre normas legais e não legais produz o consenso social necessário para assegurar que o governo se comprometa em proteger os direitos de propriedade e de contratos. Idem, p. 25, 26.

$167 \mathrm{O}$ fato de a Grã-Bretanha manifestar todas essas três características por um tempo muito longo sem uma constituição escrita e com um compromisso legal formal com a supremacia parlamentar oferece uma ilustração convincente dessa afirmação. 
168 Besley et al. enfatizam o papel que as leis de difamação desempenham na proteção das autoridades públicas das reportagens da mídia que poderiam ter efeitos prejudiciais sobre suas carreiras. Leis de difamação mais expansivas tendem a proporcionar um incentivo para que essas autoridades manipulem a mídia e para que os meios de comunicação cedam a elas devido à economia de custos associados à evitação de processos judiciais. Ver Besley et al., nota 66 supra, p. 7. Ver também Susan Rose-Ackerman, Corruption and Government: Causes, Consequences, and Reform, p. 166 (1999).

169 Besley, nota 66 supra, p. 7.

170 Rose-Ackerman, nota 168 supra, p. 167.

171 Carothers, nota 1 supra, p. 17-19.

172 Idem, p. 7. O ensaio foi originalmente publicado como Thomas Carothers, The Rule of Law Revival, Foreign Affairs 77:95 (1998).

173 Upham, nota 76 supra.

174 Santos, nota 8 supra, p. 282-28.

175 Rittich, nota 9 supra, p. 224.

176 Idem, p. 216, 247 (“... parece improvável que a boa governança e as questões jurídicas e institucionais possam ser separadas totalmente da realização de objetivos sociais”).

177 Dam, nota 6 supra, p. 231.

178 Idem, p. 230.

179 Daniel Kaufmann et al., Governance Matters, (1999) (World Bank Policy Research Working Papers n. 2196) (disponível para download em: < http:fl www.worldbank.org/research >); Rethinking Governance: Empirical Lessons Challenge Orthodoxy, World Bank, Discussion Draft, Mar. 11, 2002; ver também Daniel Kaufmann et al., Governance Matters VII: Governance Indicators for 1996-2007 (2008); Governance Redux: The Empirical Challenge. In: The Global Competitiveness Report (Xavier Sala-i-Martin, ed., 2004).

180 Daniel Kaufmann, Governance Redux: The Empirical Challenge, p. 14 (2004).

181 Rodrik et al., nota 73 supra.

182 Francis Fukuyama, Development and the Limits of Institutional Design, Global Development Network, São Petersburgo, Rússia, (20.01.2006).

183 Edward L. Glaeser et al., Do Institutions Cause Growth?, J. Econ. Growth 9:271 (2004).

184 Ver Dam, nota 6 supra.

185 William Easterly \& Ross Levine, Tropics, Germs and Crops: How Endowments Influence Economic Development, J. Monetary Econ. 50:3 (2003); Rodrik et al., nota 73 supra. Acemoglu, Johnson e Robinson também mostram que nas excolônias europeias, as regiões mais prósperas em 1500 eram, em geral, as menos prósperas e tinham as instituições jurídicas menos eficientes em 1995. A inversão de prosperidade ocorreu no final do século XIX e início do XX, coincidindo com a industrialização. Se instituições jurídicas fossem determinantes cruciais da prosperidade e os fatores geográficos fossem os determinantes fundamentais da qualidade institucional, então a "Inversão da Fortuna" não teria ocorrido; as regiões que eram prósperas em 1500 deveriam ter ficado com instituições relativamente boas e permanecido prósperas. Alguém pode argumentar que a ocorrência da Inversão da Fortuna sugere que outros fatores além da geografia determinam a qualidade das instituições jurídicas. Porém, também é possível que as instituições que a geografia realmente molda não são fundamentais para a prosperidade porque as regiões que eram prósperas em 1500 tinham instituições jurídicas ruins.

186 Idem. 
268 A RELAÇÃo ENTRE DIREITO E DESENVOLVIMENTO: OTIMISTAS VERSUS CÉTICOS

187 Esse não é de forma alguma um mapeamento abrangente da literatura empírica pertinente. Há indícios de que fatores políticos, além daqueles que mencionamos, desempenham um papel na explicação da estrutura das instituições jurídicas. Por exemplo, ao analisar dados de 1995 obtidos em 153 países, Stephenson encontrou indícios de que a independência judicial está associada à estabilidade democrática em longo prazo e com um sistema político competitivo. Ele sugere que isso é consistente com a ideia de que a independência judicial surge quando os principais partidos preveem períodos alternados no governo e na oposição e são suficientemente avessos ao risco e voltados para o futuro para aceitar restrições mútuas (judicialmente impostas) às suas ações, e uma doutrina judicial que é suficientemente moderada para evitar o aparecimento de parceria política. Porém, o modelo de Stephenson explica somente uma fração da variação em independência judicial nos países de sua amostra (em cada um de seus modelos, o pseudo-R2 está entre 0,26 e 0,27 ) e como ele mesmo admite, não pode deixar de lado a possibilidade de que a independência judicial cause a estabilidade democrática e a competição política, em vez de ser causada por elas. Stephenson, nota 59 supra.

188 Para uma crítica metodológica detalhada das limitações desses estudos, ver Andrew Williams \& Abu Siddique, The Use (and Abuse) of Governance Indicators in Economics: A Review, Economics of Governance (2007).

189 Ver também Francis Fukuyama, State-Building: Governance and World Order in the 21st Century (2004).

190 Rodrik et al., nota 73 supra, p. 157, 158.

191 Ver de modo mais geral, Rodrik, nota 53 supra.

192 Rohini Pande \& Christopher Udry, Institutions and Development: A View from Below, Yale University, 18.11 .2005

193 Ver os estudos em Beyond Common Knowledge: Empirical Approaches to the Rule of Law (Erik Jensen \& Thomas Heller, eds., 2003); ver também Trebilcock \& Daniels, nota 2 supra.

194 Ver, e.g. Kevin Davis, What Can the Rule of Law Variable Tell Us About Rule of Law Reforms?, 26 Mich. J. Int. L. 26:141 (2004); Kevin Davis \& Michael B. Kruse, Taking the Measure of Law: The Case of the Doing Business Project, Law \& Soc. Inquiry 32:1095 (2007); Williams \& Siddique, nota 188 supra.

195 Ver Sharun Mukand \& Dani Rodrik, In Search of the Holy Grail: Policy Convergence, Experimentation, and Economic Performance, Am. Econ. Rev. 95:374 (2005).

Kevin E. Davis

40 Washington Square South, 335

Nova lorque, NY 10012

davisk@juris.law.nyu.edu

84 Queen's Park

Toronto, Ontario, Canada, M5S 2C5

michael.trebilcocklatoronto.ca
Michael J. Trebilcock

PROFESSOR DA University OF TORONTO FACULTY OF LAW I 